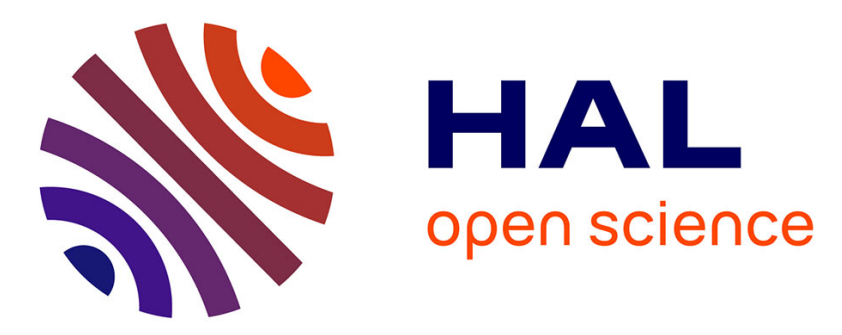

\title{
21st century climate change scenario for the Mediterranean using a coupled Atmosphere-Ocean Regional Climate Model
}

\author{
Samuel Somot, Florence Sevault, Michel Déqué, Michel Crépon
}

\section{To cite this version:}

Samuel Somot, Florence Sevault, Michel Déqué, Michel Crépon. 21st century climate change scenario for the Mediterranean using a coupled Atmosphere-Ocean Regional Climate Model. Global and Planetary Change, 2008, 63 (2-3), pp.112-126. 10.1016/j.gloplacha.2007.10.003 . hal-00195051

\section{HAL Id: hal-00195051 \\ https://hal.science/hal-00195051}

Submitted on 13 Dec 2007

HAL is a multi-disciplinary open access archive for the deposit and dissemination of scientific research documents, whether they are published or not. The documents may come from teaching and research institutions in France or abroad, or from public or private research centers.
L'archive ouverte pluridisciplinaire HAL, est destinée au dépôt et à la diffusion de documents scientifiques de niveau recherche, publiés ou non, émanant des établissements d'enseignement et de recherche français ou étrangers, des laboratoires publics ou privés. 


\section{$21^{\text {st }}$ Century Climate Change Scenario for the Mediterranean using a coupled Atmosphere-Ocean Regional Climate Model}

S. Somot, F. Sevault, M. Deque, M.CREPON

S. Somot(1, corresponding author), F. SEVAult (1), M. DÉQué (1), M.CrÉPON (2)

(1) CNRM-GAME, Météo-France, Centre National de Recherches Météorologiques, 42 avenue G. Coriolis, 31057 Toulouse cedex 1, France

Email: samuel.somot@meteo.fr

Tel: +33561079362

Fax: +33561079610

(2) LOCEAN-IPSL, UPMC, 4 place jussieu, 75005 Paris, France

Global and Planetary Change, Special Issue, MedCLIVAR, EGU 2006

submitted, September, 2006 


\section{Abstract}

The SAMM (Sea Atmosphere Mediterranean Model) has been developed to study the climate evolution of the Mediterranean and European regions for the 21st Century. SAMM is a new concept of AORCM (Atmosphere-Ocean Regional Climate Model), where a global atmosphere model is locally coupled with a regional ocean circulation model. It consists of the global spectral AGCM ARPEGE-Climate model, whose variable resolution is maximum in the Mediterranean region $(50 \mathrm{~km})$, which has been coupled to the Mediterranean Sea limited area OGCM OPAMED (10 km). A 140year numerical experiment starting in 1960 was run with the AORCM. Up to year 2000, forcing was prescribed from observed values, whereas forcing following a SRES-A2 scenario was applied beyond 2000. In order to ensure the model stability, a simple monthly heat flux correction on air-sea exchanges was applied. The presentclimate validation proves that the AORCM is comparable to the state-of-the-art European Atmosphere Regional Climate Models (ARCM) at the same resolution.

At first order, the climate change impact over Europe simulated by the AORCM is comparable with ARCM simulations. However the AORCM significantly amplifies the climate change signal over large parts of Europe with respect to the corresponding ARCM: the warming is higher in all seasons and in many areas of Europe (up to $25 \%$ of the signal), winters are wetter over northern Europe and summers drier over southern and eastern Europe (up to $50 \%$ of the signal). These differences are highly significant and the choice between coupled and non-coupled regional models could be an additional source of uncertainty when evaluating the climate change response over Europe. The factors responsible for these differences are discussed. Among them, the response of the Mediterranean SST, better simulated by the high resolution Mediterranean Sea model of the AORCM, seems to be preponderant. Further 
mechanism studies and model inter-comparisons are however required to legitimate the present results.

KEYWORDS: Climate change, regional climate modelling, air-sea coupling, Europe, Mediterranean, coupled model 


\section{Introduction}

According to the Third Assessment Report of the Intergovernmental Panel on Climate Change (IPCC 2001), the climate over the Mediterranean basin may become warmer and drier during the $21^{\text {st }}$ Century. It has even been described as one of the main climate change "hot-spots" (Giorgi 2006) in a study based on changes in the mean and in the interannual variability of temperature and precipitation. These results of $21^{\text {st }}$ Century climate change scenarios have been obtained both with global oceanatmosphere coupled climate models (Giorgi and Bi 2005, Giorgi 2006) and with atmosphere only regional climate models (Gibelin and Déqué 2003, Déqué et al. 2005, Gao et al. 2006, Christensen and Christensen 2007). However each of these approaches has its own shortcoming. The global coupled models or AOGCMs (Atmosphere-Ocean General Circulation Models) that take into account oceanatmosphere interactions do not resolve the spatial scales required to correctly represent the Mediterranean climate. This climate is strongly driven by the regionalscale mountains, valleys and local winds, which are not resolved until the spatial resolution reaches approximately $50 \mathrm{~km}$ (Li et al 2006).

Over Europe and the Mediterranean Basin, the state of the art of regional models or ARCMs (Atmosphere Regional Climate Models) that resolve spatial scales up to 50 or $20 \mathrm{~km}$ do not include the ocean feedback. They often use low resolution SST anomalies coming from previously run AOGCMs with no active feedback (Christensen and Christensen 2007). The representativeness of these SST anomalies in the local seas such as the Baltic Sea, the Black Sea or the Mediterranean Sea is doubtful. Indeed, these seas are not very well simulated by the AOGCMs, which is rather worrying since the impact of the SST changes of the local seas on the regional climate is relatively important (Kjellström et al. 2005, Somot 2005, Li 2006). 
Considering the current available computer power, it is not possible to run long term high resolution global coupled simulations. Consequently, developing AtmosphereOcean Regional Climate Models (AORCM) is the practical way to test the impact of regional coupling on regional climate change. For the European area, such a model has already been set up for the Baltic Sea (Döscher et al 2002, Räisänen et al. 2004, Kjellström et al 2005). Significantly different results for climate change scenarios have been obtained by comparing the non-coupled regional model with its coupled version. Kjellström et al. (2005) claimed for instance that the SST anomaly produced by the AORCM along the $21^{\text {st }}$ Century is far more realistic that the one deduced from an AOGCM.

However, the Mediterranean Sea is more complex to simulate than the Baltic Sea. The long (some decades) memory of the Mediterranean sea state is mainly due to the long overturning time of the Mediterranean ThermoHaline Circulation (MTHC). The MTHC is an anti-estuarine circulation (Wüst 1961), which enables the storage of a large amount of heat because it can transfer surface water anomalies towards the intermediate and deep layers (Somot et al 2006). Moreover the MTHC is known to have different stability states (deep or intermediate, Béthoux and Gentili 1999, Myers and Haines 2002) that can affect the SST pattern and, subsequently, the regional climate. Recent modelling studies suggest that the MTHC could be strongly weakened during the $21^{\text {st }}$ Century under the influence of the global climate change (Thorpe and Bigg 2000; Somot 2005; Bozec 2006; Somot et al. 2006). Such an event could impact the regional climate and should be taken into account when assessing the climate change response over the Euro-Mediterranean area. Therefore, since the simulation of the MTHC requires high resolution atmospheric fluxes (Myers et al. 1998, Somot 2005) as well as a high resolution ocean model (Madec et al. 1991, Lascaratos and 
Nittis 1998), the use of a high resolution atmosphere-ocean regional climate model (AORCM) seems to be suitable.

The CNRM (Centre National de Recherches Météorologiques) has developed an AORCM coupling a variable resolution version of the global ARPEGE-Climate model and a Mediterranean limited area version of the OGCM OPA called OPAMED. As far as we know, this new model named S.A.M.M. for Sea-Atmosphere Mediterranean Model is the first AORCM dedicated to the Mediterranean Basin. It is described in Section 2 along with the validating dataset. This paper aims at addressing two different goals. The first one is to validate this new coupled model. This is done by comparing the simulated atmospheric fields with observed data and with the corresponding ARCM in a non-coupled mode (Section 3). The second goal consists in describing the AORCM climate change response and analyzing the differences between the AORCM and the corresponding ARCM in terms of climate change for the Euro-Mediterranean area (Section 4). The representativeness of the obtained differences compared to other uncertainty sources evaluated in the European project PRUDENCE (Déqué et al 2007) will be discussed in Section 5 as well as the comparison with the corresponding AOGCM. We conclude in Section 6. This paper is dedicated to the study of the SST and of the atmospheric fields. The oceanic validation of the AORCM has been carried out in Somot (2005) and the analysis of the ocean response to the climate change will be done in another paper except for the analysis of the sea level change that is studied in Tsimplis et al (2007, this issue). 


\section{Data and model setup}

\subsection{Data}

The atmospheric data used in this study are the CRU data (New et al. 2002). They are globally gridded on a $0.5^{\circ}$ resolution grid over land areas. 2-meter temperature and precipitation are available monthly for the $20^{\text {th }}$ Century. They were used to validate the mean state and the interannual variability of the SAMM model during the 19611990 period. European boxes has been defined following Christensen and Christensen (2007) and Jacob et al (2007) in order to simplify the readability of this validating section. The boxes are defined in Table 1 (or in Figure 4 in Christensen and Christensen 2007). Only land points are considered.

\section{TABLE 1}

Concerning the sea, the only parameter validated in this study is the SST, as it is the one known to mainly influence the climate. The ARCM was forced by the so-called RSSTs (Smith et al 1996), which are also used for the validation. The RSST dataset shows a weak interannual variability for the Mediterranean Basin due to the way the dataset was created. Therefore, we also use the SST analysis of the more recent ERA40 reanalysis (Simmons and Gibson 2000) to validate the SST variability of the model. Note however that the weakness of the interannual variability of the RSST dataset does not seem to influence the results of the current study as shown in section 3.2.

\subsection{Model description}

\subsubsection{Regional coupling strategy}


Different ways of doing regional climate modelling have been described in the literature for both ocean and atmosphere models. One can either use high resolution global circulation models, limited area regional climate models forced by data (often reanalysis for the atmosphere or temperature and salinity $3 \mathrm{D}$ climatology for the ocean data) or a global variable resolution model focused on the area of interest.

Consequently, AORCMs dedicated to a particular area can be based on different types of regional climate and ocean models. However, the general principle is always the same: an air-sea coupling is applied only over a part of the domain and data are used to force the model elsewhere. For example, Döscher et al. (2002) used an ARCM forced by lateral boundary conditions taken from the ERA15 reanalysis and coupled to a regional ocean model of the Baltic Sea forced by climatological data in the North Sea. Aldrian et al (2005) also used an ARCM forced by the ERA15 and NCEP reanalyses but coupled to a global stretched ocean model forced by additional atmospheric forcing outside the coupling domain.

The Mediterranean Sea is a semi-enclosed basin separated from the Atlantic Ocean by the narrow and shallow strait of Gibraltar. The time scales associated with the Mediterranean Sea temporal variability are ten times smaller than those of the Atlantic THC (10-100 years versus 1000 years). So it is logical to simulate it with a limited area ocean model forced by 3D ocean data in a buffer zone dealing with the Atlantic Ocean as in Döscher et al. (2002). Moreover, the Mediterranean basin being located in the mid-latitudes, it is influenced by and in turn influences many global climate processes such as the NAO, the African monsoon and the Indian monsoon (see Lionello et al. 2006 for a review). Finally, the complex orography surrounding the basin, the local climate and the Mediterranean cyclogenesis require spatial high resolution (Somot 2005). We have consequently chosen a global and stretched AGCM to represent the atmospheric part of the coupled model. 


\subsubsection{The regional atmosphere model}

In the present study, we used the variable resolution version (or stretched version) of the ARPEGE-Climate model (Déqué and Piedelievre 1995). This stretching ability allows this version of ARPEGE-Climate to be at the same time an AGCM because it is global and an ARCM because of its high resolution over the area of interest.

The model used here is the same as in Gibelin and Déqué (2003) and we just recall here its main features. The spectral truncation is T106, with 31 vertical levels located mainly in the troposphere (exactly those of the ERA15 reanalysis, Gibson et al. 1997). The time step is $30 \mathrm{~min}$. The pole of stretching is located at the centre of the Mediterranean basin $\left(40^{\circ} \mathrm{N}, 12^{\circ} \mathrm{E}\right)$ and the stretching factor is 3 . The grid has 120 pseudo-latitudes and 240 pseudo-longitudes (with a reduction near the pseudo-poles to maintain the isotropy of the grid). As a result, the maximum horizontal resolution reaches $0.5^{\circ}$, which corresponds to approximately $50 \mathrm{~km}$ over the Mediterranean Basin, and has a minimum of $4.5^{\circ}$ in the Pacific.

Déqué and Piedelievre (1995) and Machenhauer et al. (1998) have shown that the variable resolution version of ARPEGE-Climate realistically reproduces the seasonal and geographical variations of the main climatological parameters over Europe. The climate simulation is reasonably close to the CRU climatology (New et al. 2002) over Europe and around the Mediterranean Basin as shown by Gibelin and Déqué (2003) and Jacob et al (2007), the largest deficiency being a too rainy winter.

\subsubsection{The high resolution Mediterranean Sea model}

In this study, we used a Mediterranean Sea limited area version of the primitive equation numerical model Ocean PArallel (OPA, Madec et al. 1998). This model, called OPAMED, is based on the 8.1 version of OPA and is consequently very close 
to the one developed for the MERCATOR project (http://www.mercator-ocean.fr, Drillet et al. 2005; Béranger et al. 2004; Alhammoud et al. 2005). It is described in details in Somot (2005) and Somot et al. (2006) in which it has been used to study the impact of the climate change on the Mediterranean Sea with atmospheric forcing provided by ARPEGE-Climate. Forcing from the ERA40 reanalysis (Somot 2005) and from the ECMWF analysis (Bozec et al. 2006) have also been tested for present climate studies.

The horizontal resolution of OPAMED is $1 / 8^{\circ} \times 1 / 8^{\circ} \cos (\phi), \phi$ being the latitude. This is equivalent to a range of 9 to $12 \mathrm{~km}$ from the north to the south of the domain with square meshes. It has 43 vertical Z-levels with a stretched distribution (from $\Delta \mathrm{Z}=6 \mathrm{~m}$ at the surface to $\Delta \mathrm{Z}=200 \mathrm{~m}$ at the bottom with 25 levels in the first $1000 \mathrm{~m}$ ). The maximum depth is $4100 \mathrm{~m}$ in the Mediterranean Sea (Eastern Basin).

The OPAMED grid is tilted and stretched at the Gibraltar Strait to better follow the SW-NE axis of the real strait. The Gibraltar Strait is represented with a two grid-point wide strait. The Atlantic ocean was modelled as a buffer zone with a restoring to climatology as described in Somot et al (2006). A time step of 20 minutes was applied.

\subsubsection{The regional coupled model}

The regional coupled model used in this study was based on the coupling of the two models described above: ARPEGE-Climate and OPAMED. They were coupled with the OASIS coupler (Valcke et al. 2000) with a daily time step. Over the coupling zone (ocean model domain), the models exchange SST, heat, water and momentum fluxes. Technical details about the coupling can be found in Sevault et al (2002) and Somot (2005). 
It is worth noting that the use of a Mediterranean Sea limited area model for the ocean leads to neglect a possible global feedback loop. Indeed, we assumed that the influence of the Mediterranean Outflow Waters (flowing into the Atlantic Ocean at a $1000 \mathrm{~m}$ depth) on the Atlantic SST (through the Atlantic thermohaline circulation) and then on the Euro-Mediterranean climate is weak.

\subsection{Models setup and simulations}

In this paper, we compared two 140-year simulations (1961-2099) following the SRES-A2 scenario (IPCC 2001). One is performed with the ARCM in a standalone mode and the other with the AORCM. The IPCC-A2 scenario is a pessimistic scenario in which the $\mathrm{CO}_{2}$ concentration is about 815 ppm in 2099.

\subsubsection{Simulation with the ARCM}

The experimental set-up (SST and radiative forcing) was the same as in Gibelin and Déqué (2003). Up to year 2000, SST was prescribed from interannual observed data (Smith et al. 1996). GHG gas and aerosol concentrations were imposed from observed values. Then, from 2000 onwards, the simulation was forced by SRES-A2 radiative forcing (GHG and aerosol concentrations). Modified SSTs were also used as surface boundary conditions for the ARCM. They were computed exactly as in Gibelin and Déqué (2003) except for the choice of the SRES scenario (A2 instead of B2). This computation used global low resolution AOGCM simulations (A2 scenario and control run) coming from the CNRM (Royer et al. 2002, Douville et al. 2002) to obtain SST anomalies. These anomalies were then simply added to Smith et al (1996) climatology in order to force the ARCM.

The year numbering corresponds to the SST chronology used to force the atmospheric model. This does not imply that the daily atmospheric circulation of the model (or 
even the climate of the year) coincides with the actual one since no other data were assimilated in the model. Only the climate statistics are reproduced by climate models. We performed a 1 year long spin-up (1960) in order to stabilize the soil scheme.

\subsubsection{Simulation with the AORCM}

Up to year 2000, the same observed data as for the ARCM were applied as boundary conditions except for the Mediterranean SST (coupling zone). The coupled simulation was performed without any relaxation at the sea surface nor in the deep layers but we applied a heat flux correction (see below).

Explicit river runoff discharges were applied to make the water budget more realistic. A monthly mean climatology covering the $1900-1984$ period was extracted from the RivDis UNESCO database (Vörösmarty et al. 1996). For the Nile River, we only kept the data collected after the Aswan dam was built in 1964. In OPAMED, the Black Sea was considered as a river with a fresh water flux equal to the E-P-R budget of the Black Sea (Stanev et al. 2000).

We simulated the Atlantic Ocean by a buffer zone $\left(6^{\circ} \mathrm{W}-11^{\circ} \mathrm{W}, 32^{\circ} \mathrm{N}-40^{\circ} \mathrm{N}\right)$ where we applied a 3D relaxation towards the Reynaud et al (1998) climatology as described in Somot et al. (2006). The relaxation was weaker close to the Gibraltar Strait (100day restoring time scale) than it was by the western limit of the model (3-day at $\left.11^{\circ} \mathrm{W}\right)$.

Initial conditions were taken from the MEDATLAS-II database (MEDAR/MEDATLAS Group, 2002) for the Mediterranean Sea and from the Reynaud et al. (1998) climatology for the Atlantic part of the model. A 20-year long spin-up was run before starting to study the simulation. The first 10 years were performed with OPAMED in the standalone mode and a strong 3D relaxation for 
temperature and salinity, whereas the 10 last years of the spin-up were run with the coupled model.

After year 2000, the SST outside the Mediterranean Sea and the radiative forcings evolved as they did in the ARCM run. River discharges and buffer zone T-S characteristics also changed following the A2 scenario using an anomaly mode. The Atlantic T-S anomalies were computed as differences between a given year and the present-climate state from the outputs of the AOGCM already used to compute the SST anomalies for the ARCM simulation. For the river discharges, the anomalies were applied as multiplying factors of the climatology. These factors were computed for each Mediterranean river catchment basin from the ARCM runoff outputs as a ratio between future and present climate. The anomalies were then filtered and evolved every decade from year 2000.

Details about the ocean configuration and about the implementation of the external forcing in the scenario are given in Somot (2005) and Somot et al. (2006).

\subsubsection{Heat flux correction}

Because of bias in the air-sea fluxes of ARPEGE-Climate (the heat loss is generally too strong when averaged over the whole basin in winter), a simple heat flux correction was applied in the coupled model over the Mediterranean Sea. It consists in adding a constant term in the equation of the temporal evolution of the sea surface temperature (noted T) as follows :

$$
\frac{\partial T(x, y, t)}{\partial t}=Q(x, y, t)+\bar{C}_{M}
$$

where $Q$ is the heat flux provided by the atmospheric model depending on $T$ and on atmospheric variables. $T$ and $Q$ depend on longitude $(x)$, latitude $(y)$ and time $(t)$ whereas $\bar{C}_{M}$ (equivalent to a heat flux) only depends on the month $M$ (12 values) and 
is spatially averaged over the Mediterranean Sea surface. This correction does not directly act upon the atmosphere model but influences it in removing the SST bias. It is worth noting that the correction does not change the spatial and temporal variability of the coupled model and also helps to stabilize the AORCM when it is run for a long period of time. The correction has been designed from a preliminary ocean simulation forced by ARPEGE-Climate with a SST relaxation towards observed data as well as from simulations with the AORCM. The yearly mean value of the correction is equal to $28 \mathrm{~W} / \mathrm{m}^{2}$ correcting the too strong average heat loss, whereas it amounts to -13 $\mathrm{W} / \mathrm{m}^{2}$ in August and $+69 \mathrm{~W} / \mathrm{m}^{2}$ in January. 


\section{Validation}

The validation was mainly done for the 1961-1990 period, a period long enough to take into account the interannual variability of the climate system. This validation was only done on yearly averages of model output.

\subsection{SST}

The heat loss, spatially averaged over the Mediterranean Sea and temporally over the 30-year period, amounted to $-3.9 \mathrm{~W} / \mathrm{m}^{2}$. This value is consistent with in-situ evaluations of this term which are of $-7 \pm 3 \mathrm{~W} / \mathrm{m}^{2}$ (Béthoux 1979, Bunker et al. 1982). The SST bias of the uncorrected AORCM was equal to $-0.9^{\circ} \mathrm{C}$ (1961-1990 value) with respect to the RSST data (Smith et al. 1996). The heat flux correction, used in this study, reduced the bias to $-0.1^{\circ} \mathrm{C}$ with negative values in winter and positive in summer. It is worth noting that other climatology datasets give different values compared to the RSST dataset $\left(19.5^{\circ} \mathrm{C}\right)$ for the yearly mean observed SST: $19.7^{\circ} \mathrm{C}$ for MedAtlas-II (MEDAR/MEDATLAS Group 2002), $19.6^{\circ} \mathrm{C}$ for MODB5 (Brasseur et al 1996) and $19.3^{\circ} \mathrm{C}$ for ERA40 analysis averaged over the 1961-1990 period (Simmons and Gibson 2000).

Both corrected and uncorrected AORCM simulations show an interannual standard deviation of the Mediterranean SST equal to 0.22 K (1961-1990 period, after removing the trend), which is in agreement with the ERA40 SST analysis $(\sigma=0.25$ K). Besides, we found that the heat flux correction does not modify the model interannual variability of the SST. In addition, during the same period, a trend in SST was observed: $+0.019^{\circ} \mathrm{C} /$ year (but only $+0.011^{\circ} \mathrm{C} /$ year for the $1961-1980$ period). This positive trend is caused by a weak imbalance between the yearly mean heat loss 
by the sea surface $\left(-3.9 \mathrm{~W} / \mathrm{m}^{2}\right)$ and the heat flux gain by the Gibraltar Strait transport $\left(+4.4 \mathrm{~W} / \mathrm{m}^{2}\right)$. It is concluded that the heat flux correction was efficient in correcting the AORCM biases in SST and heat flux.

\subsection{The atmospheric fields}

Over land, we performed the validation using the different boxes described in Section 2. Over these boxes, we compared the temperature at $2 \mathrm{~m}$ and the precipitation provided by the AORCM and ARCM simulations to the CRU observed gridded dataset. Tables $2 \mathrm{a}$ and $2 \mathrm{~b}$ summarize the results, showing that the regional coupled model is as good as the regional forced atmosphere model at the same resolution and close to the CRU values.

\subsubsection{Winter bias}

In winter, the AORCM shows a cold and dry bias over the southern Europe boxes (Iberian Peninsula and Mediterranean) whereas a warm bias is obtained over the Scandinavia box. In addition, the SAMM model is too rainy over the Northern European boxes. These biases have already been pointed out in ARPEGE-Climate version 3 (Gibelin and Déqué 2003, Jacob et al 2007) and are linked with the mean sea level pressure bias (model too zonal). Table $2 \mathrm{a}$ and $2 \mathrm{~b}$ also show that no statistically significant difference can be found between the AORCM and the ARCM for the winter season.

With regards to the interannual variability, the ARCM and the AORCM show the same behaviour. Their interannual standard deviations (temperature and precipitation) are never significantly different from each other even at a $90 \%$ significant level. Both models are then equivalent with respect to present climate in winter. 


\section{TABLE 2a and TABLE 2b}

\subsubsection{Summer bias}

In summer, the AORCM was too warm compared to the CRU dataset over the EastEurope box and too cold over the Mid-Europe, Scandinavia and Alps boxes. Temperature biases are nevertheless always less than $1^{\circ} \mathrm{C}$. Precipitation biases are also weak for this season (less than $0.3 \mathrm{~mm} / \mathrm{d}$ ) although the model is significantly too wet for Iberian Peninsula, France, Mid-Europe and Scandinavia. No systematic improvements were observed in the AORCM compared to the ARCM. The two models have comparable quality and the differences may be attributed to the chaotic behaviour of the atmosphere and to the inter-decadal variability of the models.

As in winter, the AORCM simulates an interannual variability that is not different from the one simulated by the ARCM. Moreover, a validation of the intermediate seasons has also been carried out (not shown) with similar conclusions for the mean and the standard deviation of the temperature and precipitation.

\subsubsection{State of the art}

Following the model intercomparison of the PRUDENCE project (Christensen et al 2002), Jacob et al. (2007) analyzed the biases of 11 ARCM runs over Europe at a 50$\mathrm{km}$ resolution over the same boxes at the present ones. These values could be seen as the state of the art of the RCM biases for climate simulations over Europe. Considering the 32 compared values (2m-temperature and precipitation, winter and summer, 8 boxes), one can tell that the AORCM was the best model in $22 \%$ of the cases, was in the first half in $69 \%$ and was the worst only one time out of 32 . 
We can thus conclude that the present AORCM is a good model when compared to the state of the art of uncoupled regional models. Moreover, the bias and the interannual variability simulated by the two models are statistically comparable. The coupled and non-coupled ARPEGE-Climate versions are then equivalent for the present-climate. 


\section{Climate change response and impact of the coupling}

In the following, the response of the models to climate change is studied in terms of the difference between the 2070-2099 and the 1961-1990 mean climatological parameters.

\subsection{Impact on the SST of the Mediterranean Sea}

In the AORCM, the yearly mean SST averaged over the Mediterranean basin (East of the Gibraltar Strait) increased by $+2.6^{\circ} \mathrm{C}$ with a minimum in spring $\left(+2.3^{\circ} \mathrm{C}\right)$ and a maximum in summer and autumn $\left(+2.9^{\circ} \mathrm{C}\right)$. This is in agreement with non-coupled ocean scenarios (Somot and Sevault 2005, Somot et al. 2006). Figure 1 shows the spatial pattern of this response. Minimum warming occurred along the Atlantic Water pathway in winter and summer and in the north-eastern part of the Mediterranean Sea in winter. Maximum warming was encountered in the shallower parts of the sea in winter (North of the Adriatic and Aegean Seas and Gulf of Gabes) and in the northwestern part in summer (Adriatic Sea, Tyrrhenian Sea and Liguro-Provençal basin).

\section{FIGURE 1}

\section{FIGURE 2}

The SST anomalies used to force the ARCM in the Mediterranean Sea were provided by a low resolution AOGCM run (Royer et al 2002, also see Figure 2). The mean SST of this model increases by $+2.5^{\circ} \mathrm{C}$ with a minimum in spring $\left(+2.1^{\circ} \mathrm{C}\right)$ and a maximum in summer $\left(+3.1^{\circ} \mathrm{C}\right)$. The yearly mean anomalies are similar in the AORCM and in the AOGCM (and consequently in the ARCM). However, the seasonal cycle of the AORCM, as well as the spatial pattern were significantly 
changed with respect to the ones of the AOGCM (as shown when comparing Figure 1 and Figure 2). Winter, spring and autumn were warmer in the AORCM whereas summer was colder. These differences are the signature of a damping of the SST anomaly seasonal cycle. The maximum warming in summer was weaker and the minimum warming in spring was stronger. In order to estimate the different behaviour of the two models, we have computed the parameter DD which is defined as :

$\mathrm{DD}=(\mathrm{AORCM}$-future $-\mathrm{AORCM}$-present $)-(\mathrm{ARCM}-$ future $-\mathrm{ARCM}$-present $)$

A positive value of DD means that the SST warming of the AORCM is stronger than that of the ARCM (and therefore of the AOGCM). Figure 3 shows a map of the DD parameter for SST. The DD value was also calculated for other variables.

\section{FIGURE 3}

The DD in SST, noted $\mathrm{DD}(\mathrm{SST})$, reached $+0.3^{\circ} \mathrm{C}$ in winter (value significantly different from zero at a $99 \%$ level with respect to the interannual variability of the AORCM SST), $+0.2^{\circ} \mathrm{C}$ in spring (significant at a $95 \%$ level), $-0.2^{\circ} \mathrm{C}$ in summer (significant at a $90 \%$ level) and $+0.04^{\circ} \mathrm{C}$ in autumn (not significant).

In winter, $\mathrm{DD}(\mathrm{SST})$ was maximum in the northern-western part of the Mediterranean basin (see Figure 3a). In spring the maximum of $\mathrm{DD}(\mathrm{SST})$ was located in the northeastern part of the basin $\left(+0.3^{\circ} \mathrm{C}\right.$ in the Levantine Basin and the Adriatic Sea). In summer, $\mathrm{DD}(\mathrm{SST})$ was minimum in the south-eastern part of the Mediterranean Sea (see Figure 3b). No spatial differences were found in autumn. The spatial differences in the SST anomaly between the models are not easy to explain but they are probably due to a better resolution of the surface currents and the thermohaline circulation of 
the Mediterranean Sea in the AORCM compared to the AOGCM where the Mediterranean is crudely modeled with a coarse grid $\left(2^{\circ}\right.$ in longitude).

\subsection{Impact on the two meter temperature and the precipitation}

For the same 8 boxes as for the validation, Tables $3 a$ and $3 b$ summarize the temperature and precipitation anomalies for the AORCM (see also Figure 4 and 5 for winter and summer) as well as the difference of the anomalies (equivalent to DD in temperature and precipitation).

\section{TABLE 3a and TABLE 3b}

At the end of the $21^{\text {st }}$ Century, a strong warming was simulated for all seasons. This warming has the same characteristics as that simulated by the regional models used in the PRUDENCE project. Déqué et al (2005) described this mean behaviour as a warming that is stronger in summer than in winter (1), stronger over land than over sea (2), warmer in the eastern part of Europe in winter (3) and in the southern part in summer (4).

These four characteristics were also found in the present simulations and are presented in Figure 4. As an example, for the France box, the AORCM warming was stronger in summer $\left(+4.6^{\circ} \mathrm{C}\right)$ than in winter $\left(+2.8^{\circ} \mathrm{C}\right)$, weaker than the East-Europe warming in winter $\left(+4.2^{\circ} \mathrm{C}\right)$ and stronger than the British Isles warming in summer $\left(+2.7^{\circ} \mathrm{C}\right)$.

\section{FIGURE 4}

\section{FIGURE 5}


In the AORCM (land points only), the weakest warming, which is nevertheless highly significant, occured in the British Isles box in spring $\left(+1.7^{\circ} \mathrm{C}\right)$ and the warmest box was the Mediterranean box in summer $\left(+5.2^{\circ} \mathrm{C}\right)$. Smaller areas with warming higher than $6^{\circ} \mathrm{C}$ can be seen in winter in Russia (Figure 4a) and in the Balkan area in summer (Figure 4b).

For precipitation, Table $3 \mathrm{~b}$ also shows a pattern consistent with the PRUDENCE results (Déqué et al 2005). A wetter climate in winter (see Figure 5a) for the northern part of Europe (significant for the British Isles, Mid-Europe, East-Europe, Scandinavia) with a drying over the Mediterranean Sea and a drier climate during summer (significant everywhere except for Scandinavia). The summer drying (see Figure 5b) was maximum for the southern part of Europe (Iberian Peninsula, France, Mediterranean, East-Europe). It reached less than one $\mathrm{mm} / \mathrm{d}$ in Romania. Note that the drying behaviour was also true for the intermediate seasons for the Iberian Peninsula, France and Mediterranean boxes (figures not shown).

Giorgi (2006) proposed to characterize the regional climate change response by using a Regional Climate Change Index (RCCI). This index is based on an ensemble of global air-sea coupled models and on regional mean precipitation change, mean surface air temperature change and change in the interannual variability of precipitation and temperature. In that study, the RCCI permits to identify the Mediterranean (MED) and North-Eastern Europe (NEE) regions as the main climate change "hot-spots" with a RCCI reaching 19. Over the 26 regions defined by Giorgi (2006), the RCCI values ranges from 5 to 19. We computed the RCCI values over the boxes used in our study as well as over the regions defined by Giorgi (2006). We used a global warming value of $+3.25^{\circ} \mathrm{C}$ in order to compute the Regional Warming 
Amplification factor (RWAF, see Giorgi and Bi 2005). The corresponding average global precipitation change amounted to $+4 \%$ in the AORCM. These values were computed from the AORCM simulation (2070-2099 period) including ocean areas. The main difference with the study of Giorgi (2006) is that we computed the RCCI using summer (June-July-August) and winter (December-January-February) values instead of wet and dry season values to be consistent with the frame of our study.

For the AORCM, RCCIs equal to 19 and 20 were obtained over the MED and NEE regions defined by Giorgi (2006) in good agreement with his study. Moreover RCCIs higher than 16 were obtained over all our own boxes included in the MED and NEE regions: 20 over Iberian Peninsula (IP), 17 over the Mediterranean (MD) and 24 over East-Europe (EE). The good agreement with Giorgi's results allows us to have some confidence in the climate change signal simulated by the AORCM and singles out the Mediterranean Basin and North-Eastern Europe as the climate change "hot-spots" of the AORCM simulation.

\subsection{Impact of the coupling}

Now, we would like to describe the differences between the responses of the AORCM and the ARCM by comparing the two corresponding runs. Only statistically significantly differences, underlined in grey in Tables $3 \mathrm{a}$ and $3 \mathrm{~b}$, will be pointed out and discussed.

The warming simulated by the AORCM was stronger than the ARCM one. Such a statement is true over a large part of the domain in winter (Figure 6a) mainly in the northern part of Europe (British Isles, France, Mid-Europe, Alps, East-Europe). The DD value was rather large: it reached $+0.9^{\circ} \mathrm{C}$ over the East-Europe box, that is to say it accounts for $20 \%$ of the AORCM warming. 


\section{FIGURE 6}

In spring, the area in which the warming is stronger in the AORCM than in the ARCM is restricted to the East-Europe box $\left(+0.9^{\circ} \mathrm{C}\right)$ whereas it also reached the Mediterranean box in summer $\left(+0.8^{\circ} \mathrm{C}\right.$, Figure $\left.6 \mathrm{~b}\right)$. In autumn, no significant signal appeared in the box averages. However, the warming was significantly weaker in the AORCM over the Middle East.

Concerning the precipitation in winter (Figure 7a), the AORCM was generally wetter than the ARCM in northern Europe even if only the British Isles box was significantly affected (the AORCM anomaly was twice as high as the ARCM anomaly). The summer drying at the end of the Century was significantly stronger in the AORCM (Figure $7 b$ ) over the same regions as for the temperature (Mediterranean, EastEurope) and also in autumn over the Mediterranean box. In these cases as well, the climate change signal of the AORCM was more than twice that of the ARCM.

\section{FIGURE 7}

The AORCM-ARCM differences in terms of climate change response seem to be rather large compared to the climate change signal itself. Moreover these changes are spatially and physically consistent (see Figures $6 \mathrm{a}, 6 \mathrm{~b}, 7 \mathrm{a}, 7 \mathrm{~b}$ ) as well as statistically significant with respect to the interannual variability (see Tables $3 a$ and $3 b$ ). All these differences are compared to other sources of uncertainty in Section 5.

\subsection{Understanding of the coupling impact}

\subsubsection{Winter}


In winter, climate change responses can be often explained by changes in the large scale circulation whose signature is well marked on the mean sea level pressure (MSLP). Figure 8 represents a map of DD(MSLP) in winter expressing the difference of the anomalies between the AORCM and the ARCM (see Equation 2 for a definition). A significant negative DD(MSLP) was observed over the north of Europe, which was centred in Scandinavia $(\mathrm{DD}(\mathrm{MSLP})=-4 \mathrm{hPa}$ in the Scandinavia box, statistically significant with a $95 \%$ level).

\section{FIGURE 8}

This favours the advection of Atlantic air mass over central Europe, which is responsible for the observed temperature and precipitation anomalies (see Figures 6a and 7a). A dipole pattern can also be noted for the cloud cover and the water available for precipitation with higher values over northern Europe and lower values in the south. It is worth noting that the AORCM-ARCM difference in terms of $2 \mathrm{~m}$ temperature, precipitation, water content and cloud cover looks like a NAO+ pattern. The link between the DD(SST) (larger warming for the AORCM in the north-western part of the Mediterranean Sea) and the DD(MSLP) is not yet explained and is not consistent with sensitivity studies performed with an atmosphere model forced by SST that has been modified over the Mediterranean Sea (Li 2006).

\subsubsection{Spring}

Like in winter, the DD(MSLP) showed a negative anomaly but now located over central Europe. This could lead to an enhanced advection of warm and wet air masses coming from the Mediterranean Sea in the AORCM compared to the ARCM. In addition, the $\mathrm{DD}(\mathrm{SST})$ is positive in spring and more important in the north-eastern 
part of the Mediterranean Sea in the AORCM. Both these effects could contribute to warm East-Europe. Finally, a positive feedback of the snow cover seems to be sufficient to create the $\mathrm{DD}\left(\mathrm{T}_{2 \mathrm{~m}}\right)$ described for the $\mathrm{EE}$ box $\left(+0.9^{\circ} \mathrm{C}\right.$, see Table $3 \mathrm{a}$ and Figure 9).

\section{FIGURE 9}

\subsubsection{Summer}

For the summer, Rowell and Jones (2006) proposed three "driver" mechanisms and one positive feedback for explaining a higher drying and warming over eastern Europe and the Mediterranean area in the climate change context. These mechanisms can be used to explain the AORCM-ARCM differences.

The first driver mechanism is linked with a lower soil moisture (SM) in spring. As no significant $\mathrm{DD}(\mathrm{SM})$ was obtained in spring, this mechanism is not relevant in our case. The second one is based on large-scale circulation differences. This mechanism does not correspond to the AORCM - ARCM difference either, because no significant DD(MSLP) was found in summer. The last one however seems to explain part of our signal. It is based on a larger land-sea contrast leading to an increase in atmospheric water-holding capacity higher over land than over sea. This implies a strongly reduced relative humidity for continental air masses advected from the maritime areas leading to a decrease in convective precipitation, cloud cover and an increased warming (increase in short-wave radiation, warming by sensible heat flux, decrease in evaporation). This third driver mechanism corresponds to the AORCM situation because the SST warming was lower in the AORCM than in the ARCM in summer, whereas the continental warming was higher, thus increasing the land-sea contrast. 
The positive feedback between the soil moisture depletion in summer and the decrease in evaporation and convective activity, which was also mentioned by Rowell and Jones (2006), is also supposed to play an important role in the simulated AORCM-ARCM differences by amplifying the "land-sea contrast" mechanism.

These mechanisms (land-sea contrast and summer soil moisture feedback) are reinforced by the fact that the atmospheric water divergence (E-P) over sea increases less in the scenario in the AORCM than in the ARCM. This leads to negative DDs with respect to the water vapour (see Figure 10), cloud cover (see Figure 11) and soil water content over the Mediterranean countries and East-Europe areas. The summer drying and warming of this part of Europe is consequently enhanced (see Figure 6b and $7 b)$.

\section{FIGURE 10}

\section{FIGURE 11}

\subsubsection{Autumn}

In autumn, changes between the ARCM and the AORCM do not concern Europe but the Middle East. In the AORCM, there was a large increase in atmospheric water divergence over the Eastern part of the Mediterranean Sea together with a water convergence over the Middle East with more clouds and more rain explaining the observed temperature and precipitation changes (figures not shown). As the AORCM and the ARCM simulated equivalent SST differences, (same seasonal mean, same spatial pattern), high-frequency coupling processes must explain this significant difference. However, the study of these processes is complex and requires computationally expensive sensitivity tests with the AORCM that are beyond the scope of this paper. 


\section{Discussion}

\subsection{How large are the coupled/non-coupled differences?}

From the previous results, we can claim that a source of uncertainty in predicting the climate change in Europe could come from the choice between an ARCM and an AORCM with an interactive Mediterranean Sea. Now we would like to evaluate how large this new source of uncertainty is in comparison to other sources due to model choice and pointed out by the European PRUDENCE project (Christensen and Christensen 2007). These other sources in regional climate modelling comprise the choice of the ARCM for a given forcing GCM, the choice of the forcing GCM, the choice of the SRES scenario and the internal model variability (Déqué et al 2007). For a given SRES scenario (A2 for example), Déqué et al (2007) proved that the larger sources of uncertainty lie in the choice of the forcing GCM in all seasons and in the choice of the ARCM only in summer.

Note that the uncertainty linked to the internal model variability of a given RCM or of a given GCM has not been evaluated in this study. For atmosphere models, this internal variability can be linked to different initial states of the atmosphere or to different SST forcings. We assume that this internal model variability is negligible with respect to the other sources of uncertainty what is often true (Déqué et al., 2007). For the AORCM, we also assume that the initial state of the Mediterranean Sea model is not an important source of internal model variability. This should be evaluated through ensemble simulations in the future.

Using the four GCMs and the eleven RCMs of the PRUDENCE project, we were able to compute the InterModel Distance (IMD) for temperature and precipitation denoted 
$I M D_{G C M}$ and $I M D_{R C M}$ respectively. The $I M D_{R C M}$ was computed using the Hadley Center GCM (HadAM3H) as a common boundary forcing for the various RCMs. These indexes can be considered as an evaluation of the uncertainty due to the choice of the model that is to say due to the spreading of the model responses around their mean response.

For example, the $I M D_{R C M}$ for temperature was computed as :

$$
I M D_{R C M}=\sqrt{\frac{2}{N(N-1)} \sum_{i<j}\left(\Delta T_{i}-\Delta T_{j}\right)^{2}}
$$

where $i$ and $j$ are used to number the models from 1 to 11 (for the RCMs); $\Delta T_{i}$ is the climate change response of the model $i$ and $N(N-1) / 2$ is the number of model couples. The larger the IMD index, the larger the difference in the model responses. Note that the $I M D$ is exactly equal to the intermodel standard deviation multiplied by $\sqrt{2}$.

The IMD computation has been carried out in the cases where there was a statistically significant difference between the AORCM and the ARCM responses as provided by the so-called DD values (see grey boxes in Tables 3a and 3b). A value of DD larger than the IMD implies that the impact of the regional coupling on the regional climate change response is greater than the impact of using different GCMs or RCMs. Results are summarized in Table $3 \mathrm{a}$ for temperature and Table $3 \mathrm{~b}$ for precipitation.

In three seasons (winter, spring and autumn) and for two parameters (temperature and precipitation), DD was always larger than $I M D_{R C M}$ and had, at least, the same order of magnitude as $I M D_{G C M}$. In summer, the situation is the same as in winter over the Mediterranean box but different over the East-Europe box. Indeed $I M D_{R C M}$ and $I M D_{G C M}$ are very large over this last box in summer (more than $1.3^{\circ} \mathrm{C}$ and $0.4 \mathrm{~mm} / \mathrm{d}$ ) and they are both larger than DD. The high value of $I M D_{G C M}$ can be explained by the strong warming of the Hadley Center model in this area compared to other GCMs. 
For $I M D_{R C M}$, the high value of the index is explained by the physics of the EasternEurope climate in summer: convective weather situations, strong atmosphere-land interaction and important contribution of the soil water content in the determination of the $2 \mathrm{~m}$ temperature (Rowell and Jones 2006). This specific climate and these threshold effects on the soil water content might explain why the RCMs are so free with respect to their common lateral boundary conditions and then able to diverge. Our study proves that whatever the summer behaviour over the EE box may be, the uncertainty due to using coupled or non-coupled RCM is large and should not be neglected a priori. Consequently this new source of uncertainty should be taken into account when dealing with European climate change.

\subsection{Comparison with the AOGCM response}

In order to acquire a better understanding of the differences between the AORCM and the ARCM responses to climate change (DD values), we also compared their responses to that of the corresponding AOGCM (same physics, Royer et al 2002). The AOGCM and the ARCM have the same SST response to climate change by construction (see Section 2) whereas the AORCM has a different response in SST (see Section 4). However, over the Mediterranean Sea surface, the AOGCM and the AORCM are coupled and the ARCM is forced. But, the ARCM and the AORCM have the same resolution over the Mediterranean Sea whilst the AOGCM has a lower one. Therefore, comparing the three model responses to climate change could also help to find out which factor among the resolution, the Mediterranean coupling or the Mediterranean SST difference sparks off the observed AORCM-ARCM differences.

Gibelin and Déqué (2003) have already compared the ARCM and the AOGCM in SRES-B2 simulations in the same configuration (the SST response of the AOGCM 
was used to force the ARCM). They concluded that the resolution has a weak effect on the climate change impact at the European scale.

The comparison between the three models was carried out over the boxes where the DD parameters were significantly different from zero (see Tables $3 a$ and $3 b$ ). In winter, for all the significant boxes, we found that the AOGCM response is equal to the ARCM response even if these models have a different resolution and a different coupled/non-coupled mode. This implies that the AORCM-ARCM differences would only be explained by the Mediterranean SST difference given by the two models during this season. This SST difference is mainly due to an explicit simulation of the Mediterranean thermohaline circulation due to the high-resolution ocean part of the AORCM.

The same behaviour was observed in spring for the temperature over the East-Europe box showing that the difference in SST response is the source of the AORCM-ARCM difference, as it is in winter. The ARCM, AORCM, AOGCM comparison did not bring clear conclusion in autumn.

In summer the situation is different. Over the Mediterranean and East-Europe boxes, the AOGCM response was very similar to the AORCM response. The prevailing factor explaining the DD values is consequently the coupling over the Mediterranean Sea because the non-coupled ARCM has a different response. For this season, the interactive Mediterranean Sea enhanced the simulated warming for the areas under Mediterranean influence. 


\section{Conclusion}

As far as we know, this is the first time that the climate change response over Europe and the Mediterranean basin has been studied using a high resolution coupled Atmosphere-Ocean Regional Climate Model (AORCM). The SAMM model (SeaAtmosphere Mediterranean Model) coupling a global variable-resolution atmosphere model (50-km over the Mediterranean area) to a 10-km Mediterranean Sea model has been designed to represent the major atmospheric and oceanic characteristics of the Mediterranean basin which is mainly driven by orography, small scale physical processes and narrow straits. A SRES-A2 scenario has been carried out with SAMM from 1960 to 2099. An anomaly mode was used to simulate the evolution of the external forcing (SST outside the Mediterranean Sea, Atlantic T-S characteristics, river runoff fluxes) in addition to the GHG and aerosol concentrations.

A simple heat flux correction was successfully applied over the Mediterranean Sea. It allowed us to remove the SST bias and to ensure the model stability without changing either the SST spatial variability or the interannual variability. Moreover, we verified that the AORCM was as good as the corresponding ARCM (ARPEGE-Climate) for the present climate and belongs to the state-of-the-art of the European regional climate models.

The climate change simulated by the AORCM shows an important warming at the end of the $21^{\text {st }}$ Century for all seasons with maximum values (higher than $+6^{\circ} \mathrm{C}$ ) in the eastern part of Europe in winter and in the southern part of Europe in summer. A drying was generally simulated over Europe and the Mediterranean Basin except for northern Europe where the climate mainly becomes wetter. Over southern Europe, the 
decrease in precipitation between the 1961-1990 period and the 2070-2099 period often reached $-30 \%$ in summer.

We showed that the spatial and seasonal patterns of the climate change over Europe simulated by the AORCM were comparable with non-coupled regional simulations run with the corresponding ARCM or with other European RCMs. However, the climate change signal was enhanced over Europe in the AORCM simulation. In winter, the warming is significantly larger over the following areas: British Isles, France, Mid-Europe, Alps and Eastern-Europe with values reaching $+0.9^{\circ} \mathrm{C}$ for the AORCM-ARCM difference in the climate change response (up to $25 \%$ of the signal). The north of Europe is also wetter in the AORCM in winter. These differences can be explained by a MSLP anomaly that is probably linked to a higher warming of the Mediterranean SST in the AORCM. In summer, the Mediterranean and the EastEurope areas are significantly warmer (25\% of the signal) and drier (50\% of the signal) in the AORCM. Three factors could explain the former behaviour: a weaker warming of the AORCM SST for that season, a weaker humidity advection from the Mediterranean Sea to these areas and a positive feedback of the soil water content. High-frequency coupling interactions could also be part of the explanation as well as differences in the spatial pattern of the Mediterranean SST response. Differences in spring and autumn were also pointed out but were not so well explained.

A better consistency between the SST, the air-sea fluxes and the vertical structure of the atmosphere (air-sea coupling) as well as a better representation of the Mediterranean thermohaline circulation and the SST pattern (high resolution ocean model) are probably the key-processes explaining the differences between the AORCM and the ARCM (with SST coming from a previous AOGCM run). They also give more confidence in the AORCM results over the Euro-Mediterranean area. 
However, a detailed study of the ocean part of the AORCM simulation (compared to the forced ORCM simulation or to the ocean part of the AOGCM run) is needed to better understand that point. Moreover, mechanism studies through sensitivity tests would also be necessary to really understand which processes might explain the differences described in winter and summer. Using the simulated SST response of the AORCM (spatially filtered or not) to force the ARCM model could help understanding the roles of the mean SST difference, the SST pattern difference and the coupling effect.

Compared to other sources of uncertainty arising when evaluating the European climate change through regional climate modelling (PRUDENCE project), the choice between non-coupled and coupled RCMs appears to be as important as the choice of the RCM or the choice of the forcing GCM are. This result confirms the results obtained by Kjellström et al (2005) for the Baltic Sea. Therefore, we recommend that this new source of uncertainty should not be neglected when evaluating the climate change response over Southern and Eastern Europe, which are the areas where the impact of the regional coupling seems to be the most important. However a multimodel approach is necessary to legitimate the results of our study. For example, ensemble simulations performed with the same AORCM and different initial ocean states are required to estimate the internal variability of these models. This multimodel approach should be achieved through a dedicated international cooperation between different research centres owing to the enormous computing effort required. It is actually planned in the European CIRCE project where 6 different AORCMs dedicated to the study of the Mediterranean climate change will be used. We hope that this intercomparison framework will also allow to develop non-flux corrected regional coupled models for the Mediterranean Sea in comparing and improving the air-sea flux parameterizations within the RCMs. 


\section{Acknowledgments}

This work was supported by the ENSEMBLES European project (contract GOCE-

CT-2003-505539) financed by the European Commission under the $6^{\text {th }}$ Framework Programme and by the CYPRIM project in the program ACI - FNS "Aléas et Changements Globaux" of the Ministère de l'Enseignement et de la Recherche (French Research Department). We also thank Dr. Aurore Voldoire for computing AOGCM values, Dr Sébastien Conil, Dr Anna Pirani, Dr Nellie Elguindi and Jeanne Colin for helpful comments and suggestions.

\section{References}

Aldrian, E., Sein, D., Jacob, D., Dümenil Gates, L., Podzum, R., 2005. Modelling Indonesian rainfall with a coupled regional model. Clim. Dyn., 25: 1-17, doi: 10.1007/s00382-004-0483-0.

Alhammoud, B., Béranger, K., Mortier, L., Crépon, M., Dekeyser, I., 2005. Surface circulation of the Levantine Basin: comparison of model results with observations. Prog. Oceanogr., 66(2-4): 299320.

Béranger, K., Mortier, L., Gasparini, G., Gervasio, L., Astraldi, M., Crépon, M., 2004. The dynamic of the Sicily Strait: A comprehensive study from observations and models. Deep-Sea Res. II, 51(45): 411-440.

Béthoux, J.P., 1979. Budgets of the Mediterranean Sea. Their dependence on the local climate and on the characteristics of the Atlantic waters. Oceanologica Acta, 2: 157-163.

Béthoux, J.P., Gentili, B., 1999. Functioning of the Mediterranean Sea: Past and present changes related to freshwater input and climatic changes. J. Mar. Syst., 20: 33-47.

Bozec, A., 2006. La circulation thermohaline de la Mer Méditerranée sous les climats présent et future. Ph.D. Thesis, Université Paris VI, France. 
Bozec, A., Bouruet-Aubertot, P., Béranger, K., Crépon, M., 2006. Mediterranean oceanic response to the interannual variability of a high-resolution atmospheric forcing : a focus on the Aegean Sea. J. Geophys. Res., V111(C11013), doi:10.1029/2005JC003427.

Brasseur, P., Beckers, J., Brankart, J., Schoenauen, R., 1996. Seasonal temperature and salinity fields in the Mediterranean Sea: Climatological analyses of a historical data set. Deep Sea Res., 43: 159192.

Bunker, A., Charnock, H., Goldsmith, R., 1982. A note on the heat balance of the Mediterranean and Red Seas. J. Mar. Res., 40: 73-84.

Christensen, J.H., Carter, T.R., Giorgi, F., 2002. PRUDENCE employs new methods to assess European climate change. EOS, 83: 147.

Christensen, J.H., Christensen, O., 2007. A summary of the PRUDENCE model projections of changes in European climate by the end of this century. Climatic Change, 81(1): 7-30, doi: $10.1007 / \mathrm{s} 10584-006-9210-77-30$.

Déqué, M., Piedelievre, J.P., 1995. High-Resolution climate simulation over Europe. Clim. Dyn., 11: 321-339.

Déqué, M., Jones, R.G., Wild, M., Giorgi, F., Christensen, J.H., Hassell, D.C., Vidale, P.L., Rockel., B., Jacob, D., Kjellström, E., de Castro, M., Kucharski, F., van den Hurk, B., 2005. Global high resolution versus Limited Area Model scenarios over Europe: results from the PRUDENCE project. Clim. Dyn., 25: 653-670.

Déqué, M., Rowell, D., Lüthi, D., Giorgi, F., Christensen, J.H., Rockel, B., Jacob, D., Kjellström, E., de Castro, M., van den Hurk, B., 2007. An intercomparison of regional climate models for Europe: assessing uncertainties in model projections. Climatic Change, 81(1): 53-70, doi: 10.1007/s10584-006-9228-x.

Döscher, R., Willén, U., Jones, C., Rutgersson, A., Meier, H.E.M., Hansson, U., 2002. The development of the coupled ocean-atmosphere model RCAO. Boreal Env. Res., 7: 183-192.

Douville, H., Chauvin, F., Royer, J.F., Salas-y-Mélia, D., Tyteca, S., 2002. Sensitivity of the hydrological cycle to increasing amounts of greenhouse gases and aerosols. Clim. Dyn., 20: 4568. 
Drillet, Y., Bourdallé-Badie, R., Siefridt, L., Le Provost, C., 2005. The MEDDIES in the Mercator North Atlantic and Mediterranean Sea eddy-resolving model. J. Geophys. Res., 110(C03016), doi:10.1029/2003JC002170.

Gao, X., Pal, J.S., Giorgi, F., 2006. Projected changes in mean and extreme precipitation over the Mediterranean region from high resolution double nested RCM simulation. Geophys. Res. Lett., 33:L03706, doi:10.1029/2005GL024954.

Gibelin, A.L., Déqué, M., 2003. Anthropogenic climate change over the Mediterranean region simulated by a global variable resolution model. Clim. Dyn., 20: 327-339.

Gibson, J.K., Kållberg, P., Uppala, S., Hernandez, A., Serano, E., 1997. ERA description. ECMWF Reanalysis project report series. ECMWF, Shinfield Park, Reading, RG2 9AX, UK.

Giorgi, F., Bi., X., 2005. Updated regional precipitation and temperature changes for the $21^{\text {st }}$ century from ensembles of recent AOGCM simulations. Geophys. Res. Lett., 32:L21715, doi:10.1029/2005GL024288.

Giorgi, F., 2006. Climate change hot-spots. Geophys. Res. Lett., 33:L08707, doi:10.1029/2006GL025734

IPCC, 2001. Climate Change 2001. The scientific basis. Contribution of Working Group I to the third assessment report of the IPCC. Houghton, Ding, Griggs, Noguer, Van der Linder, Dai, Maskell, Johnson (Eds). Cambridge University Press, Cambridge, UK. 881 pp.

Jacob, D., Bärring, L., Christensen, O.B., Christensen, J.H., de Castro, M., Déqué, M., Giorgi, F., Hagemann, S., Hirschi, M., Jones, R., Kjellström, E., Lenderink, G., Rockel, B., Sànchez, E.S., Schär, C., Seneviratne, S.I., Somot, S., van Ulden, A., van den Hurk, B., 2007. An intercomparison of regional climate models for Europe: Model performance in Present-Day Climate. Climatic Change, 81 (1): 31-52, doi: 10.1007/s10584-006-9213-4.

Kjellström, E., Döscher, R., Meier, H.E.M., 2005. Atmospheric response to different sea surface temperatures in the Baltic Sea: Coupled versus uncoupled regional climate model experiments. Nordic Hydrology, 36(4).

Lascaratos, A., Nittis, K., 1998. A high-resolution three-dimensional numerical study of intermediate water formation in the Levantine Sea. J. Geophys. Res., 103(C9): 18 497-18 512. 
Li, L., 2006. Atmospheric GCM response to an idealized anomaly of the Mediterranean sea surface temperature. Clim. Dyn., 27: 543-552.

Li, L., Bozec, A., Somot, S., Béranger, K., Bouruet-Aubertot, P., Sevault, F., Crépon, M., 2006. Regional atmospheric, marine processes and climate modelling (chapter 7). In: Lionello, P., Malanotte, P., Boscolo, R. (Eds), Mediterranean Climate Variability, Elsevier B.V., Amsterdam, pp. 373-397.

Lionello, P., Malanotte, P., Boscolo, R., 2006. Mediterranean Climate Variability. Lionello, P., Malanotte, P., Boscolo, R. (Eds), Elsevier B.V., Amsterdam.

Machenhauer, B., Windelband, M., Botzet, M., Christensen, J.H., Déqué, M., Jones, R., Ruti, P.M., Visconti, G., 1998. Validation and analysis of regional present-day climate and climate change simulations over Europe. MPI Report No 275, MPI, Hamburg, Germany, 87 pp.

Madec, G., Chartier, M., Delecluse, P., Crépon, M., 1991. A three dimensional numerical study of deep water formation in the northwestern Mediterranean sea. J. Phys. Oceanogr., 21(9): 1 349-1 371.

Madec, G., Delecluse, P., Imbard, M., Levy, C., 1998. OPA 8.1, Ocean General Circulation Model, Reference Manual. IPSL/LODYC, France, Note du Pôle de modélisation, 11.

MEDAR/MEDATLAS Group, 2002. MEDAR/MEDATLAS 2002 Database. Cruise inventory, observed and analyzed data of temperature and bio-chemical parameters, 4 Cdrom.

Myers, P.G., Haines, K., Josey, S., 1998. On the importance of the choice of wind stress forcing to the modeling of the Mediterranean Sea circulation. J. Geophys. Res., 103(C8): 15 729-15 749.

Myers, P.G., Haines, K., 2002. Stability of the Mediterranean's thermohaline circulation under modified surface evaporative fluxes. J. Geophys. Res., 107(C3), doi:10.1029/2000JC000550.

New, M., Hulme, M., Jones, P.D., 2002. A high-resolution data set of surface climate over global land areas. Climate Res., 21: 1-25.

Räisänen, J., Hansson, U., Ullerstig, A., Döscher, R., Graham, L.P., Jones, C., Meier, H.E.M., Samuelsson, P., Willén, U. 2004. European climate in the late twenty-first century: regional simulations with two driving global models and two forcing scenarios. Clim. Dyn., 22: 13-31.

Reynaud, T., LeGrand, P., Mercier, H., Barnier, B., 1998. A new analysis of hydrographic data in the Atlantic and its application to an inverse modeling study. International WOCE Newsletters 32: 29-31. 
Rowell, D.P., Jones, R.G., 2006. Causes and uncertainty of future summer drying over Europe. Clim. Dyn., 27: 281-299, doi:10.1007/s00382-006-0125-9.

Royer, J.F., Cariolle, D., Chauvin, F., Déqué, M., Douville, H., Planton, S., Rascol, A., Ricard, J.L., Salas-y-Melia, D., Sevault, F., Simon, P., Somot, S., Tyteca, S., Terray, L., Valcke, S., 2002. Simulation of climate changes during the 21-st century including stratospheric ozone. C.R. Géosciences, 334(3): 147-154.

Sevault, F., Somot, S., Déqué, M., 2002. Couplage ARPEGE-MEDIAS - OPA-MEDITERANEE. Les étapes. Note de Centre, CNRM, GMGEC, n. 84 (in French, available at samuel.somot@meteo.fr).

Simmons, A.J., Gibson, J.K., 2000. The ERA-40 Project Plan. ERA-40 Project Report Series (1). ECMWF. Shinfield Park, Reading, UK. 63 pp.

Smith, T., Reynolds, R., Livezey, R., Stokes, D., 1996. Reconstruction of historical sea surface temperatures using empirical orthogonal functions. J. Climate, 9: 1 403-1 420.

Somot, S., 2005. Modélisation climatique du bassin méditerranéen : variabilité et scénarios de changement climatique. Ph.D. Thesis, Université Paul Sabatier, Toulouse, France.

Somot, S., Sevault, F. 2005. Climate Change impact on the Mediterranean sea circulation : A regional modelling approach. Note de Centre, CNRM, GMGEC, n. 95 (in English, available at samuel.somot@meteo.fr).

Somot, S., Sevault, F., Déqué, M., 2006. Transient climate change scenario simulation of the Mediterranean Sea for the 21st century using a high-resolution ocean circulation model. Clim. Dyn., 27(7-8): 851-879, doi :10.1007/s00382-006-0167-z.

Stanev, E., Le Traon, P.-Y., Peneva, E., 2000. Sea level variations and their dependency on meteorological and hydrological forcing: Analysis of altimeter and surface data for the Black Sea. J. Geophys. Res., 105(C7): 17 203-17 216.

Thorpe, R.B., Bigg, G.R., 2000. Modelling the sensitivity of the Mediterranean Outflow to anthropogenically forced climate change. Clim. Dyn., 16: 355-368.

Tsimplis, M., Marcos, M., Somot, S., 2007. $21^{\text {st }}$ century Mediterranean sea level rise. Regional model predictions. Global and Planetary Change (this issue). 
Valcke, S., Terray, L., Piacentini, A., 2000. OASIS 2.4 Ocean Atmosphere Sea Ice Soil, User's Guide, CERFACS.

Vörösmarty, C., Fekete, B., Tucker, B., 1996. Global river discharge database, RivDis, vol. 0 to 7. International Hydrological Program, Global Hydrological Archive and Analysis Systems, UNESCO, Paris, France.

Wüst, G., 1961. On the vertical circulation of the Mediterranean Sea. J. Geophys. Res., 66(10): 3 261-3 271. 


\section{Figures Captions}

Figure 1: AORCM response to the climate change for the 30 -year average sea surface temperature (in ${ }^{\circ} \mathrm{C}$ ) between the $2070-2099$ period and the $1961-1990$ period (a) in winter and (b) in summer.

Figure 2: Same as Figure 1 but for ARCM SST response.

Figure 3: 30-year average sea surface temperature difference in ${ }^{\circ} \mathrm{C}(\mathrm{a})$ in winter and (b) in summer between the AORCM and the ARCM climate change responses (20702099 period minus 1961-1990 period). This is equivalent to Figure 1 minus Figure 2 that is to say a map of the DD values for the sea surface temperature (see the text for definition of DD).

Figure 4: Same as Figure 1 but for 2-meter temperature (a) in winter and (b) in summer (in $\left.{ }^{\circ} \mathrm{C}\right)$.

Figure 5: Same as Figure 1 but for precipitation (a) in winter and (b) in summer (in $\mathrm{mm} / \mathrm{d})$.

Figure 6: Same as Figure 3 (DD values) but for 2 meter temperature (a) in winter and (b) in summer (in $\left.{ }^{\circ} \mathrm{C}\right)$.

Figure 7: Same as Figure 3 but for precipitation (a) in winter and (b) in summer (in $\mathrm{mm} / \mathrm{d})$.

Figure 8: Same as Figure 3 but for mean sea level pressure (in $\mathrm{hPa}$ ) in winter.

Figure 9: Same as Figure 3 but for $2 \mathrm{~m}$ temperature (in ${ }^{\circ} \mathrm{C}$ ) in spring.

Figure 10: Same as Figure 3 but for atmosphere water vapour (in $\mathrm{mm}$ ) in summer.

Figure 11: Same as Figure 3 but for nebulosity (in \%) in summer. 


\section{Table Captions}

Table 1: Definition of the European sub-areas used in the text expressed in degrees in longitude and latitude.

Table 2a: Validation table for winter (December-January-February) and summer (June-July-August) for the two-meter temperature (in ${ }^{\circ} \mathrm{C}$, box averages for the boxes defined in Table 1): CRU data (values from Jacob et al. 2007), AORCM bias compared to CRU, and AORCM-ARCM difference. A value noted *** or ** or * means that the difference is statistically significant with a $99 \%$ or $95 \%$ or $90 \%$ significance level. The significant values are highlighted by grey boxes for the AORCM bias and the AORCM-ARCM difference.

Tab. 2b: Same as Table 2a but for precipitation (in $\mathrm{mm} / \mathrm{d}$ ).

Table 3a: Climate change impact for the 2-meter temperature for the four seasons and for the boxes defined in Table $1 . \Delta(\mathrm{AORCM})$ is the mean climate change response of the AORCM between the 1961-1990 period and the 2070-2099 period. $\Delta$ (AORCM) $\Delta(\mathrm{ARCM})$ is the difference between the AORCM and ARCM climate change responses (denoted DD in the text). A value noted $* * *$ or $* *$ or $*$ means that the difference is statistically significant with a $99 \%$ or $95 \%$ or $90 \%$ significance level. The significant values of DD are highlighted by grey boxes. The InterModel Distances $\left(\mathrm{IMD}_{\mathrm{GCM}}, \mathrm{IMD}_{\mathrm{RCM}}\right)$ are computed only for significant values of DD (see the text for the definition of IMD) and should be compared to the DD values. Table 3b: Same as Table 3a but for precipitation (in $\mathrm{mm} / \mathrm{d}$ ). 


\begin{tabular}{|l|l|l|l|l|}
\hline Area & West & East & South & North \\
\hline 1 (BI) British Isles & -10 & 2 & 50 & 59 \\
\hline 2 (IP) Iberian Peninsula & -10 & 3 & 36 & 44 \\
\hline 3 (FR) France & -5 & 5 & 44 & 50 \\
\hline 4 (ME) Mid-Europe & 2 & 16 & 48 & 55 \\
\hline $5(\mathrm{SC})$ Scandinavia & 5 & 30 & 55 & 70 \\
\hline 6 (AL) Alps & 5 & 15 & 44 & 48 \\
\hline 7 (MD) Mediterranean & 3 & 25 & 36 & 44 \\
\hline 8 (EE) East-Europe & 16 & 30 & 44 & 55 \\
\hline
\end{tabular}

Table 1: Definition of the European sub-areas used in the text expressed in degrees in longitude and latitude. 


\begin{tabular}{|c|c|c|c|c|c|c|c|c|}
\hline & $\mathrm{BI}$ & IP & FR & $\mathrm{ME}$ & $\mathrm{SC}$ & $\mathrm{AL}$ & $\mathrm{MD}$ & $\mathrm{EE}$ \\
\hline & \multicolumn{8}{|c|}{ 2-meter temperature, DJF } \\
\hline CRU data & 3.6 & 6.4 & 4.1 & 0.7 & -8.7 & -1.1 & 4.6 & -2.4 \\
\hline AORCM bias & 0.4 & $-1.9 * *$ & 0.0 & 0.5 & $1.6 * *$ & -0.4 & $-1.2 * *$ & 0.2 \\
\hline \multirow[t]{2}{*}{ AORCM - ARCM } & -0.2 & -0.2 & -0.5 & -0.5 & 0.1 & -0.5 & -0.3 & -0.5 \\
\hline & \multicolumn{8}{|c|}{ 2-meter temperature, JJA } \\
\hline CRU data & 13.8 & 20.5 & 17.6 & 16.7 & 13.0 & 15.4 & 20.6 & 17.8 \\
\hline AORCM bias & -0.3 & -0.3 & -0.3 & $-0.7 * *$ & $-0.9 * *$ & $-0.8 * *$ & 0.1 & $0.7 * *$ \\
\hline AORCM - ARCM & -0.2 & -0.5 & -0.5 & -0.4 & -0.2 & -0.4 & -0.5 & -0.4 \\
\hline
\end{tabular}

Table 2a: Validation table for winter (December-January-February) and summer (June-July-August) for the two-meter temperature (in ${ }^{\circ} \mathrm{C}$, box averages for the boxes defined in Table 1): CRU data (values from Jacob et al. 2007), AORCM bias compared to CRU, and AORCM-ARCM difference. A value noted $* * *$ or $* *$ or $*$ means that the difference is statistically significant with a $99 \%$ or $95 \%$ or $90 \%$ significance level. The significant values are highlighted by grey boxes for the AORCM bias and the AORCM-ARCM difference. 


\begin{tabular}{|c|c|c|c|c|c|c|c|c|c|}
\hline & BI & IP & FR & ME & SC & AL & MD & EE \\
\hline & \multicolumn{7}{|c|}{ precipitation, DJF } \\
\hline CRU data & 3.4 & 2.7 & 2.4 & 1.7 & 1.8 & 3.2 & 3.1 & 1.3 \\
\hline AORCM bias & 0.2 & $-0.9^{* *}$ & $0.8^{* *}$ & $1.4^{* *}$ & $0.7^{* *}$ & -0.1 & $-1.1^{* *}$ & $0.4^{* *}$ \\
\hline AORCM - ARCM & -0.2 & 0.0 & -0.1 & -0.2 & 0.0 & -0.2 & 0.0 & 0.0 \\
\hline & \multicolumn{7}{|c|}{ precipitation, JJA } \\
\hline CRU data & 2.5 & 1.1 & 1.8 & 2.3 & 2.4 & 4.0 & 1.5 & 2.6 \\
\hline AORCM bias & 0.0 & $0.2^{* *}$ & $0.3^{* *}$ & $0.3^{* *}$ & $0.3 * *$ & -0.2 & 0.2 & 0.0 \\
\hline AORCM - ARCM & 0.1 & 0.1 & 0.2 & 0.1 & 0.1 & 0.2 & 0.1 & 0.1 \\
\hline
\end{tabular}

Tab. 2b: Same as Table 2a but for precipitation (in $\mathrm{mm} / \mathrm{d}$ ). 


\begin{tabular}{|c|c|c|c|c|c|c|c|c|}
\hline & $\mathrm{BI}$ & IP & FR & $\mathrm{ME}$ & $\mathrm{SC}$ & $\mathrm{AL}$ & MD & $\mathrm{EE}$ \\
\hline & \multicolumn{8}{|c|}{ 2-meter temperature, DJF } \\
\hline$\Delta(\mathrm{AORCM})$ & $2.2 * * *$ & $2.9 * * *$ & $2.8^{* * * *}$ & $3.2 * * *$ & $4.2 * * *$ & $3.3^{* * *}$ & $3.2 * * *$ & $4.2 * * *$ \\
\hline$\Delta(\mathrm{AORCM})-\Delta(\mathrm{ARCM})$ & $0.5 * *$ & 0.3 & $0.7 * *$ & $0.8 * *$ & -0.1 & $0.7 * *$ & 0.4 & $0.9 * *$ \\
\hline \multirow[t]{2}{*}{$\mathrm{IMD}_{\mathrm{GCM}} / \mathrm{IMD}_{\mathrm{RCM}}$} & $0.6 / 0.3$ & & $0.3 / 0.4$ & $0.5 / 0.5$ & & $0.8 / 0.6$ & & $0.8 / 0.5$ \\
\hline & \multicolumn{8}{|c|}{ 2-meter temperature, MAM } \\
\hline$\Delta(\mathrm{AORCM})$ & $1.7 * * *$ & $3.3 * * *$ & $2.2 * * *$ & $2.5 * * *$ & $3.6 * * *$ & $3.0 * * *$ & $3.3 * * *$ & $4.2 * * *$ \\
\hline$\Delta(\mathrm{AORCM})-\Delta(\mathrm{ARCM})$ & 0.0 & 0.2 & 0.2 & 0.3 & 0.6 & 0.3 & 0.4 & $0.9 * *$ \\
\hline \multirow[t]{2}{*}{$\mathrm{IMD}_{\mathrm{GCM}} / \mathrm{IMD}_{\mathrm{RCM}}$} & & & & & & & & no data $/ 0.8$ \\
\hline & \multicolumn{8}{|c|}{ 2-meter temperature, JJA } \\
\hline$\Delta(\mathrm{AORCM})$ & $2.7 * * *$ & $4.8 * * *$ & $4.6 * * *$ & $3.6 * * *$ & $2.7 * * *$ & $4.7 * * *$ & $5.2 * * *$ & $4.6 * * *$ \\
\hline$\Delta(\mathrm{AORCM})-\Delta(\mathrm{ARCM})$ & 0.1 & 0.1 & 0.3 & 0.5 & -0.2 & 0.5 & $0.8 * *$ & $0.9 * *$ \\
\hline \multirow[t]{2}{*}{$\mathrm{IMD}_{\mathrm{GCM}} / \mathrm{IMD}_{\mathrm{RCM}}$} & & & & & & & $1.0 / 0.7$ & $2.0 / 1.3$ \\
\hline & \multicolumn{8}{|c|}{ 2-meter temperature, $\mathrm{SON}$} \\
\hline$\Delta(\mathrm{AORCM})$ & $3.1 * * *$ & $3.8 * * *$ & $3.7 * * *$ & $3.5 * * *$ & $3.2 * * *$ & $3.5 * * *$ & $3.6 * * *$ & $3.6 * * *$ \\
\hline$\Delta(\mathrm{AORCM})-\Delta(\mathrm{ARCM})$ & 0.2 & 0.2 & 0.5 & 0.2 & -0.3 & 0.2 & -0.1 & -0.3 \\
\hline
\end{tabular}

Table 3a: Climate change impact for the 2-meter temperature for the four seasons and for the boxes defined in Table 1. $\triangle($ AORCM) is the mean climate change response of the AORCM between the 1961-1990 period and the 2070-2099 period. $\Delta$ (AORCM) $\triangle(\mathrm{ARCM})$ is the difference between the AORCM and ARCM climate change responses (denoted DD in the text). A value noted $* * *$ or $* *$ or $*$ means that the difference is statistically significant with a $99 \%$ or $95 \%$ or $90 \%$ significance level. The significant values of DD are highlighted by grey boxes. The InterModel Distances ( $\mathrm{IMD}_{\mathrm{GCM}}, \mathrm{IMD}_{\mathrm{RCM}}$ ) are computed only for significant values of $\mathrm{DD}$ (see the text for the definition of IMD) and should be compared to the DD values. 


\begin{tabular}{|c|c|c|c|c|c|c|c|c|}
\hline & BI & IP & FR & $\mathrm{ME}$ & $\mathrm{SC}$ & $\mathrm{AL}$ & MD & $\mathrm{EE}$ \\
\hline & \multicolumn{8}{|c|}{ precipitation, DJF } \\
\hline$\Delta(\mathrm{AORCM})$ & $0.8 * * *$ & 0.0 & 0.3 & $0.4 * *$ & $0.5 * * *$ & 0.3 & -0.2 & $0.2 * *$ \\
\hline$\Delta(\mathrm{AORCM})-\Delta(\mathrm{ARCM})$ & $0.4 * *$ & -0.1 & 0.2 & 0.3 & 0.2 & 0.3 & -0.1 & 0.1 \\
\hline \multirow[t]{2}{*}{$\mathrm{IMD}_{\mathrm{GCM}} / \mathrm{IMD}_{\mathrm{RCM}}$} & $0.3 / 0.3$ & & & & & & & \\
\hline & \multicolumn{8}{|c|}{ Precipitation, MAM } \\
\hline$\Delta(\mathrm{AORCM})$ & -0.1 & $-0.5 * * *$ & -0.3 & 0.0 & $0.3 * * *$ & 0.1 & $-0.3 * *$ & $0.2 * *$ \\
\hline \multirow[t]{2}{*}{$\Delta(\mathrm{AORCM})-\Delta(\mathrm{ARCM})$} & -0.1 & 0.0 & 0.0 & -0.1 & 0.1 & 0.3 & 0.1 & 0.1 \\
\hline & \multicolumn{8}{|c|}{ precipitation, JJA } \\
\hline$\Delta(\mathrm{AORCM})$ & $-0.4 * * *$ & $-0.5 * * *$ & $-0.6 * * *$ & $-0.3 * *$ & 0.0 & $-0.4 * *$ & $-0.5 * * *$ & $-0.5 * * *$ \\
\hline$\Delta(\mathrm{AORCM})-\Delta(\mathrm{ARCM})$ & -0.1 & 0.0 & 0.0 & -0.1 & -0.1 & -0.1 & $-0.2 *$ & $-0.3^{*}$ \\
\hline \multirow[t]{2}{*}{$\mathrm{IMD}_{\mathrm{GCM}} / \mathrm{IMD}_{\mathrm{RCM}}$} & & & & & & & $0.3 / 0.2$ & $0.5 / 0.4$ \\
\hline & \multicolumn{8}{|c|}{ precipitation, SON } \\
\hline$\Delta(\mathrm{AORCM})$ & 0.2 & $-0.3 * *$ & $-0.3 * *$ & 0.0 & $0.3 * * *$ & -0.4 & $-0.4 * * *$ & -0.1 \\
\hline$\Delta(\mathrm{AORCM})-\Delta(\mathrm{ARCM})$ & -0.1 & 0.2 & -0.3 & -0.2 & -0.1 & -0.4 & $-0.3^{*}$ & -0.1 \\
\hline $\mathrm{IMD}_{\mathrm{GCM}} / \mathrm{IMD}_{\mathrm{RCM}}$ & & & & & & & $\begin{array}{c}\text { no data / } \\
0.2\end{array}$ & \\
\hline
\end{tabular}

Table 3b: Same as Table 3a but for precipitation (in $\mathrm{mm} / \mathrm{d}$ ). 
(a)

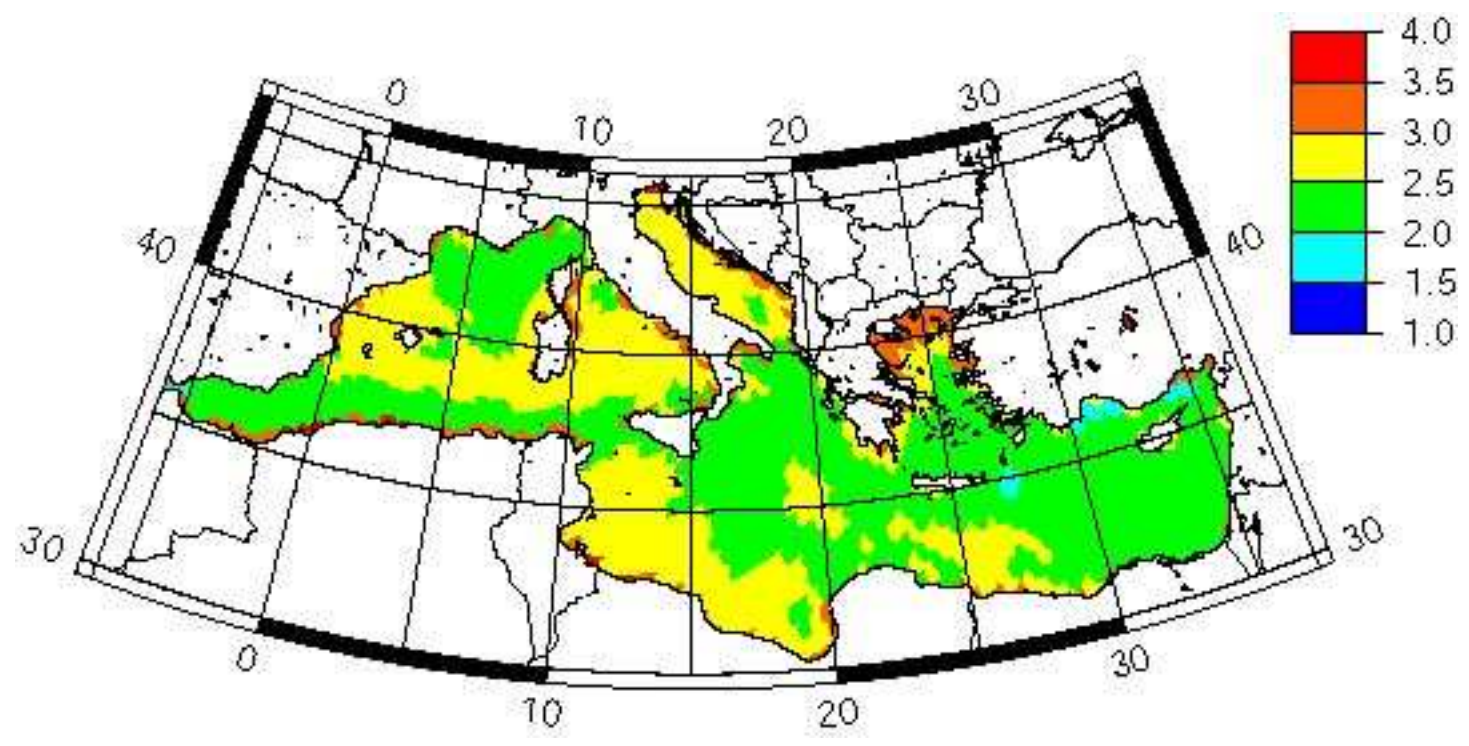

(b)

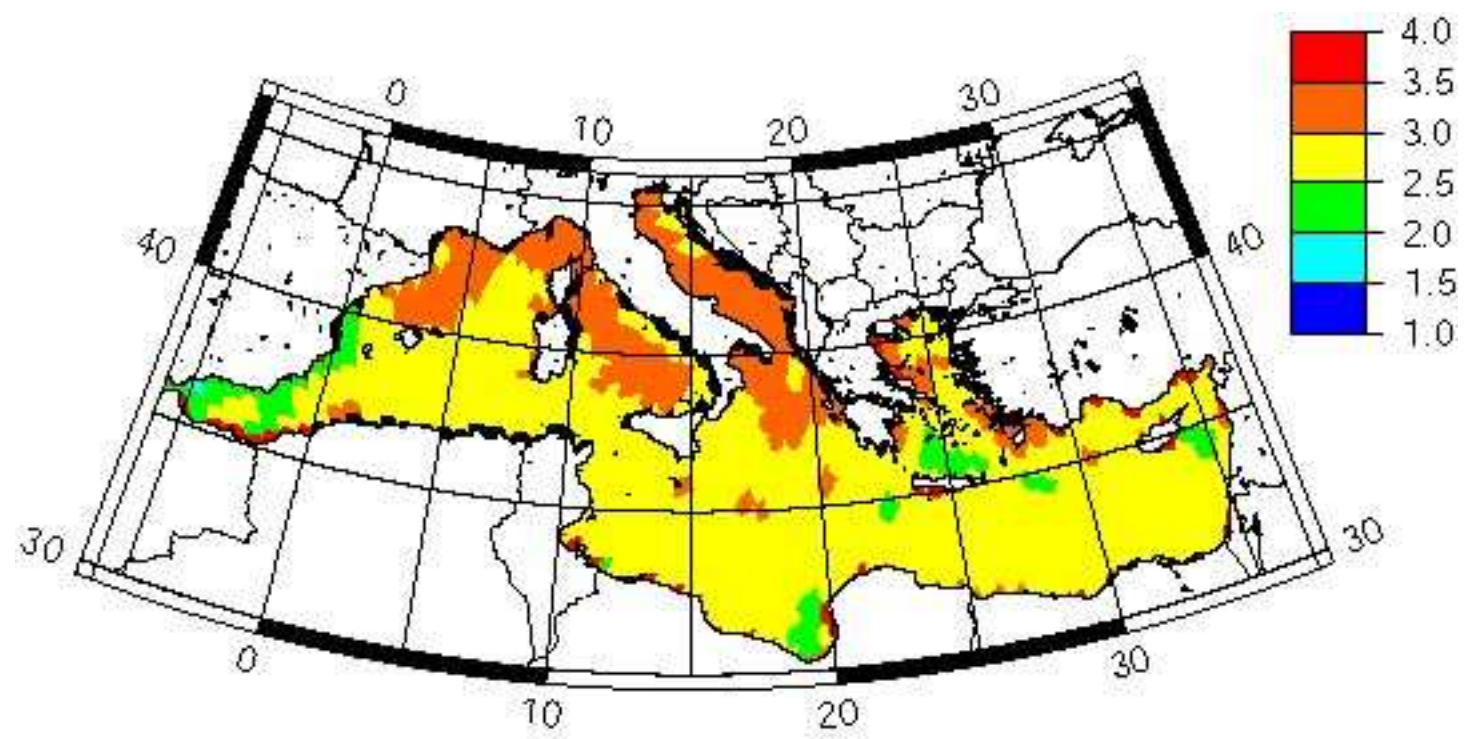

Figure 1: AORCM response to the climate change for the 30 -year average sea surface temperature (in ${ }^{\circ} \mathrm{C}$ ) between the $2070-2099$ period and the $1961-1990$ period (a) in winter and (b) in summer. 
(a)

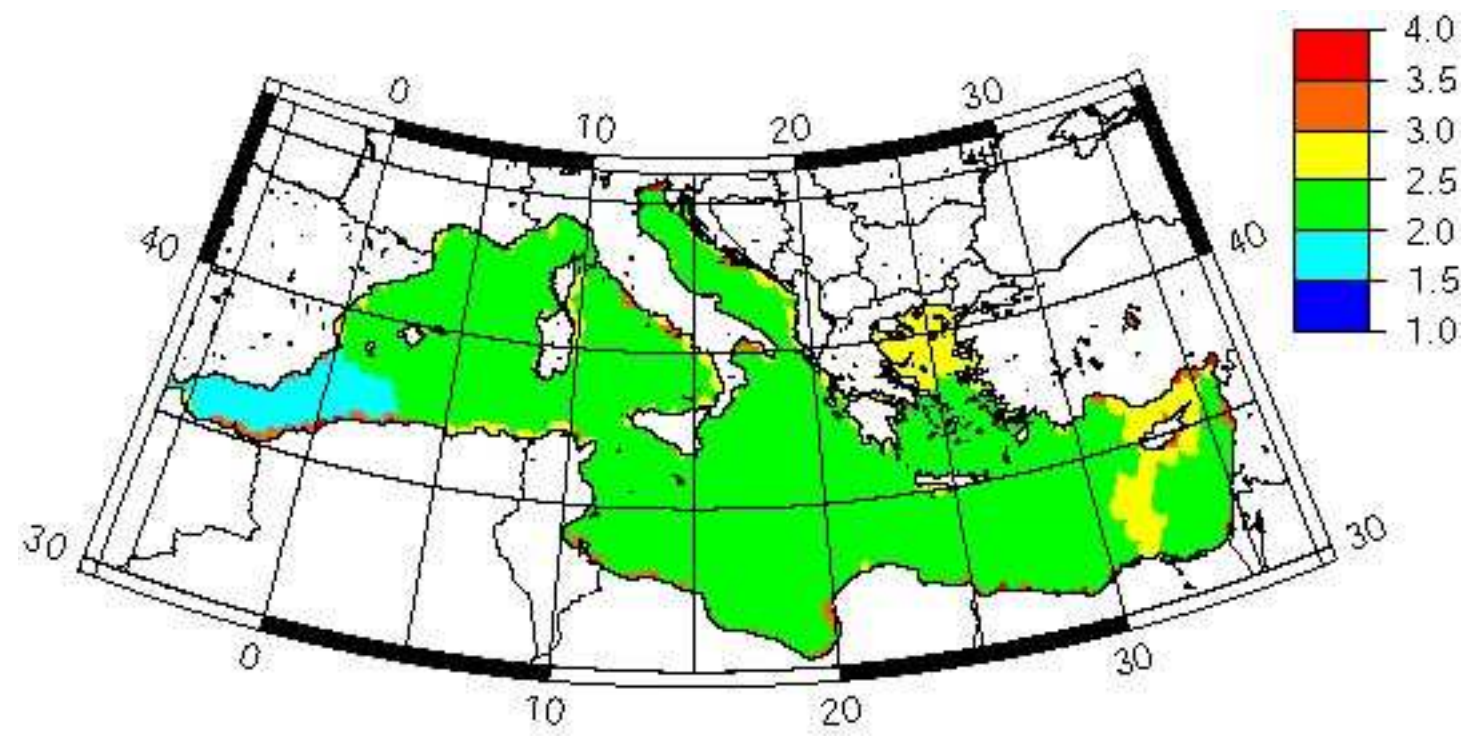

(b)

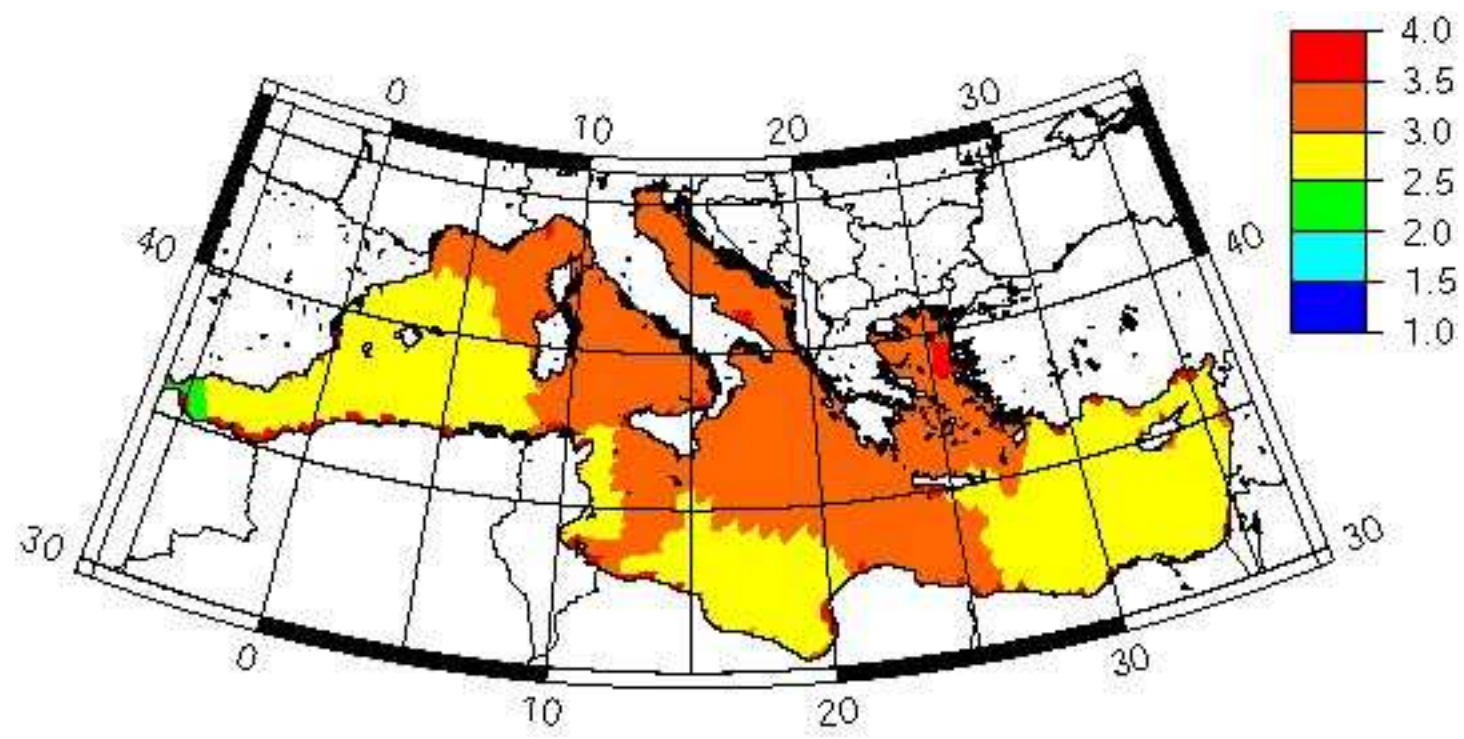

Figure 2: Same as Figure 1 but for ARCM SST response. 
(a)

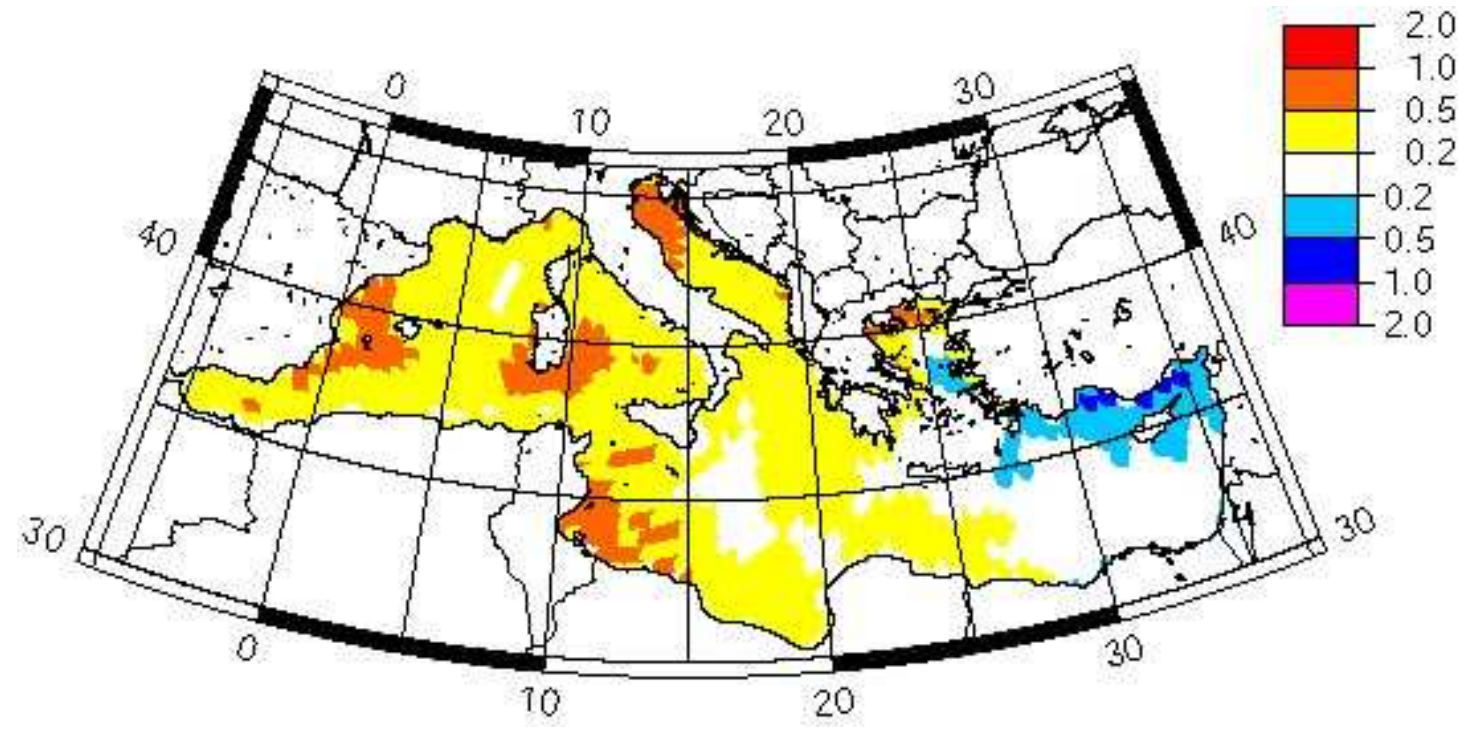

(b)

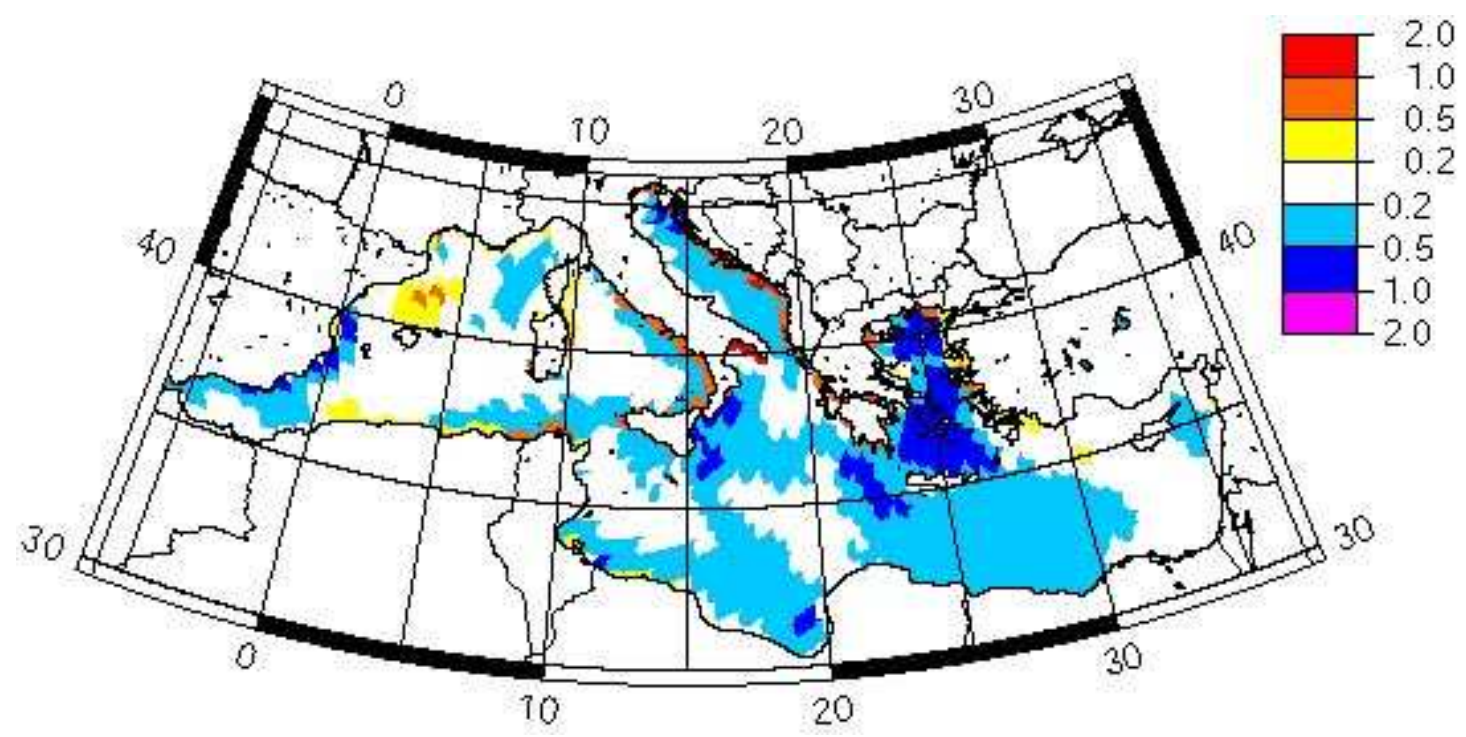

Figure 3: 30-year average sea surface temperature difference in ${ }^{\circ} \mathrm{C}$ (a) in winter and (b) in summer between the AORCM and the ARCM climate change responses (20702099 period minus 1961-1990 period). This is equivalent to Figure 1 minus Figure 2 that is to say a map of the DD values for the sea surface temperature (see the text for definition of DD). 
(a)

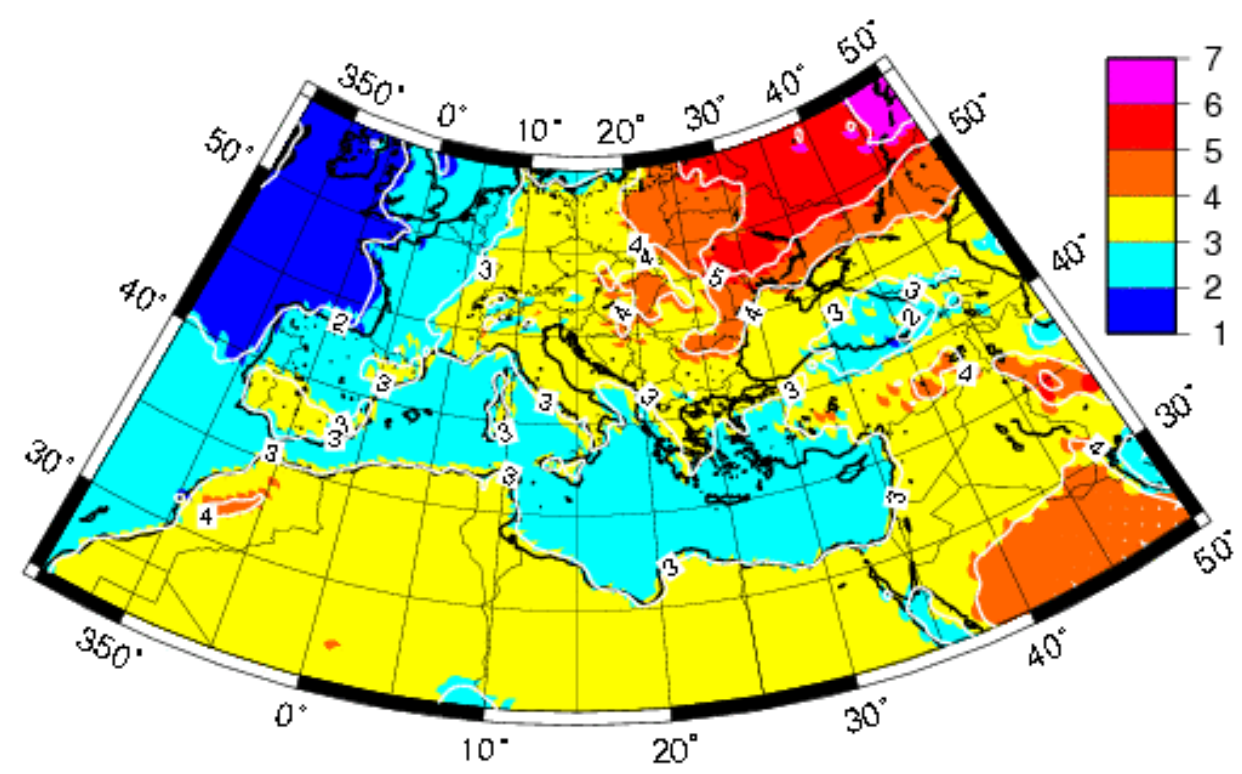

(b)

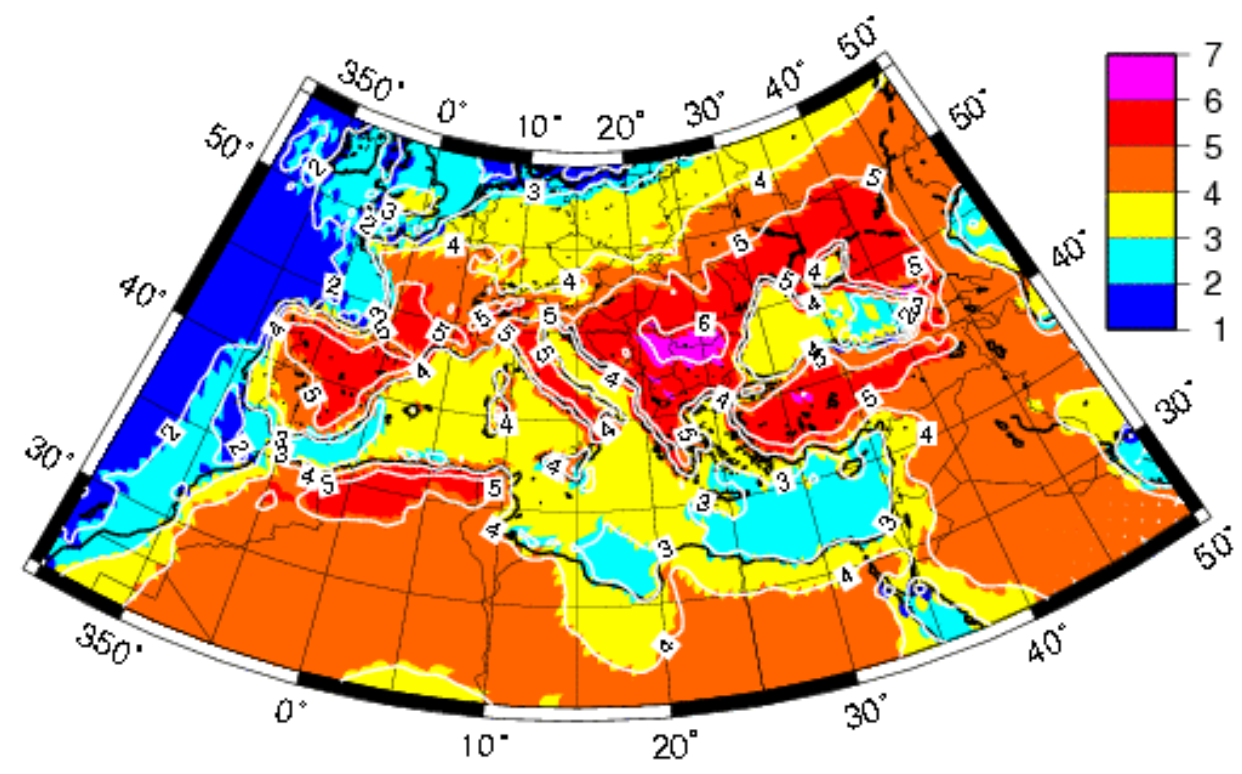

Figure 4: Same as Figure 1 but for 2-meter temperature (a) in winter and (b) in summer (in $\left.{ }^{\circ} \mathrm{C}\right)$. 
(a)

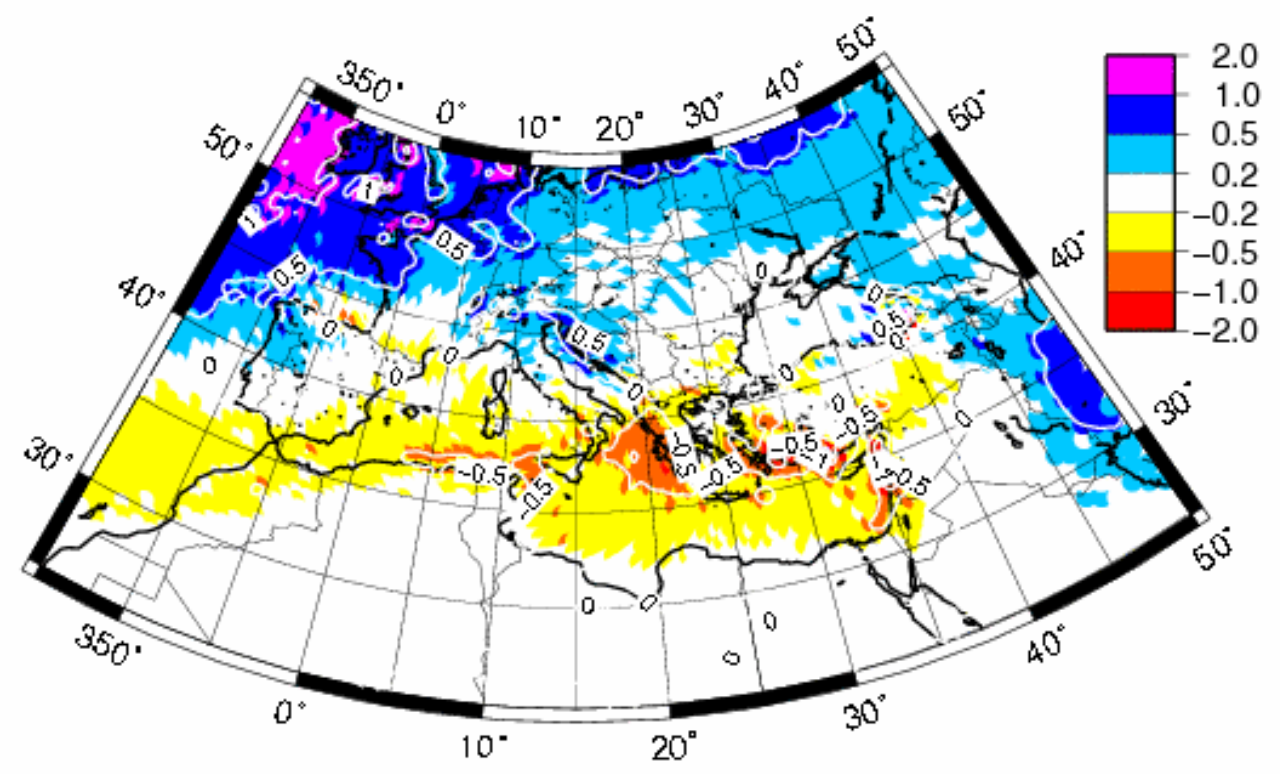

(b)

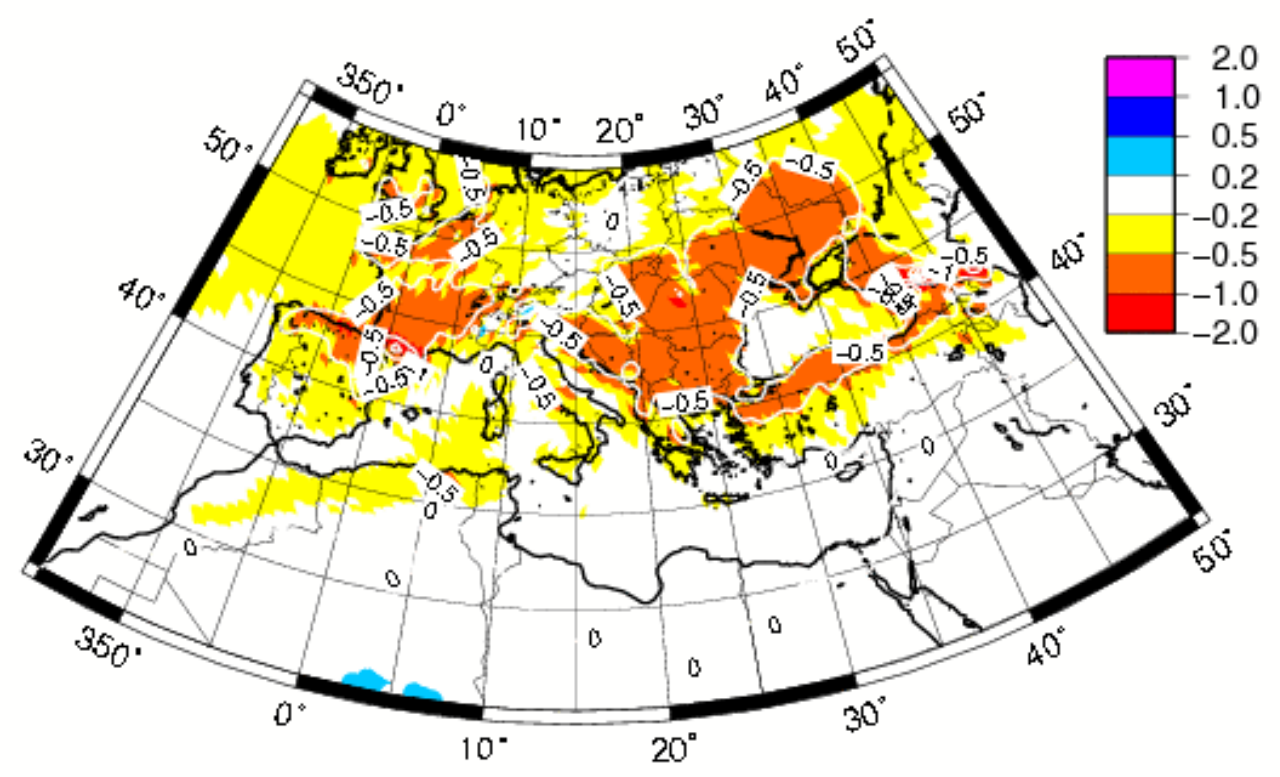

Figure 5: Same as Figure 1 but for precipitation (a) in winter and (b) in summer (in $\mathrm{mm} / \mathrm{d}$ ). 
(a)

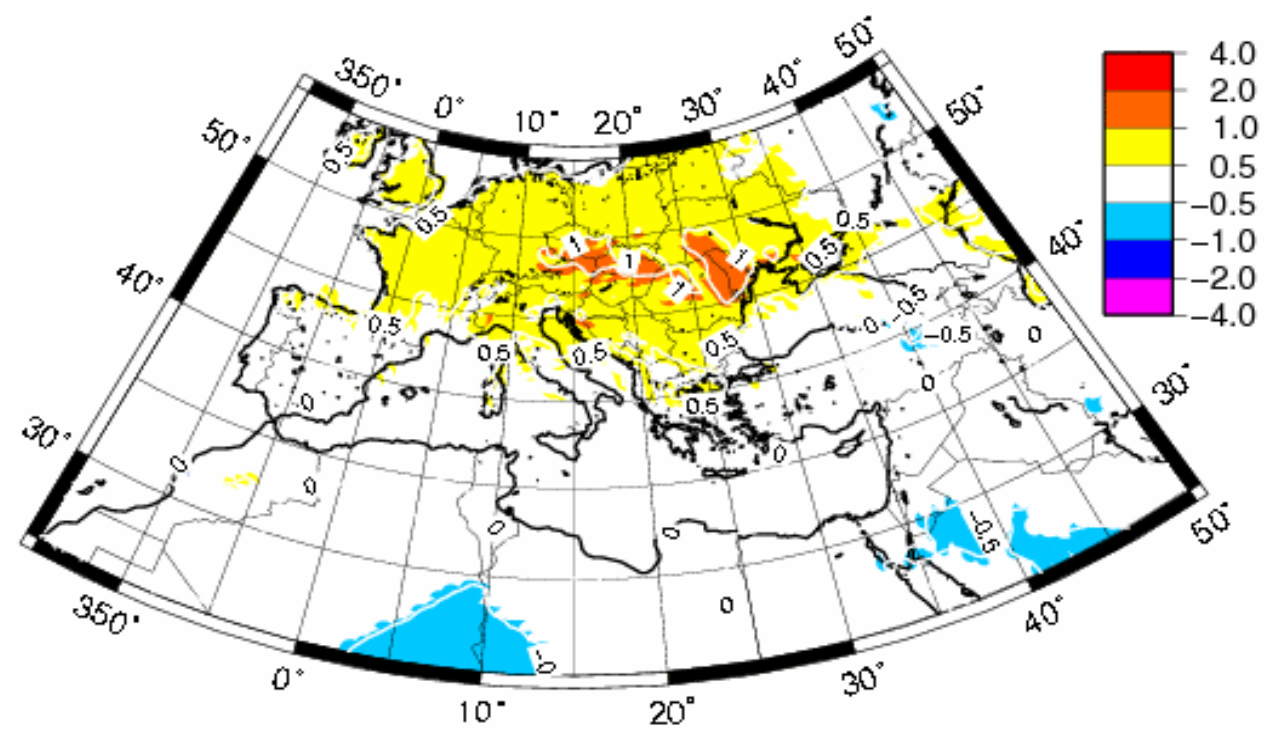

(b)

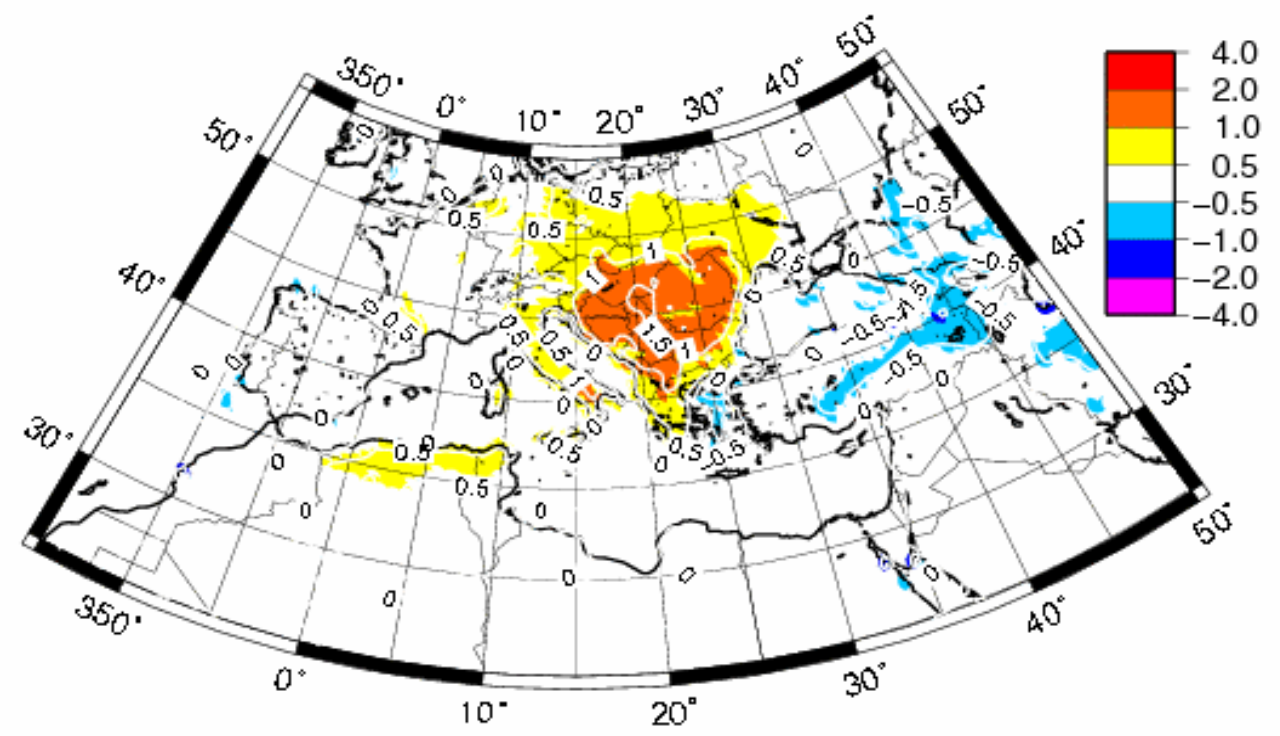

Figure 6: Same as Figure 3 (DD values) but for 2 meter temperature (a) in winter and (b) in summer (in $\left.{ }^{\circ} \mathrm{C}\right)$. 
(a)

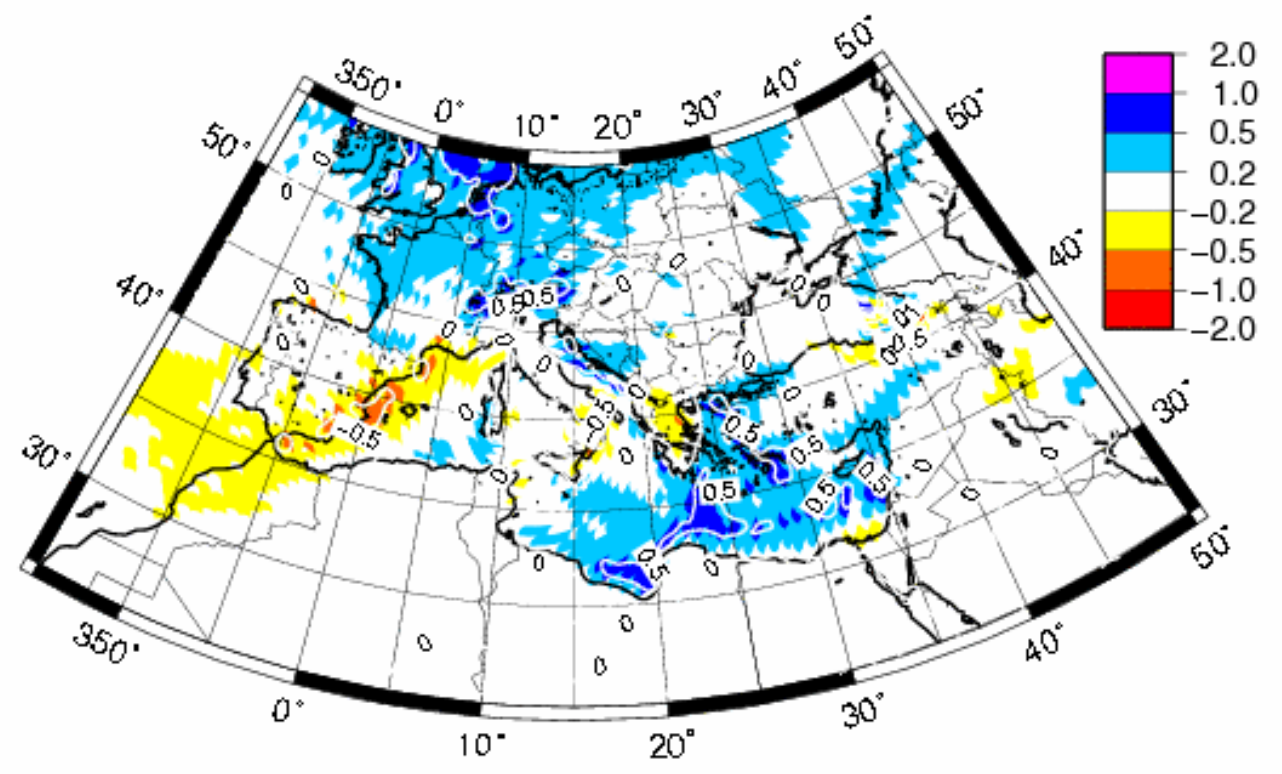

(b)

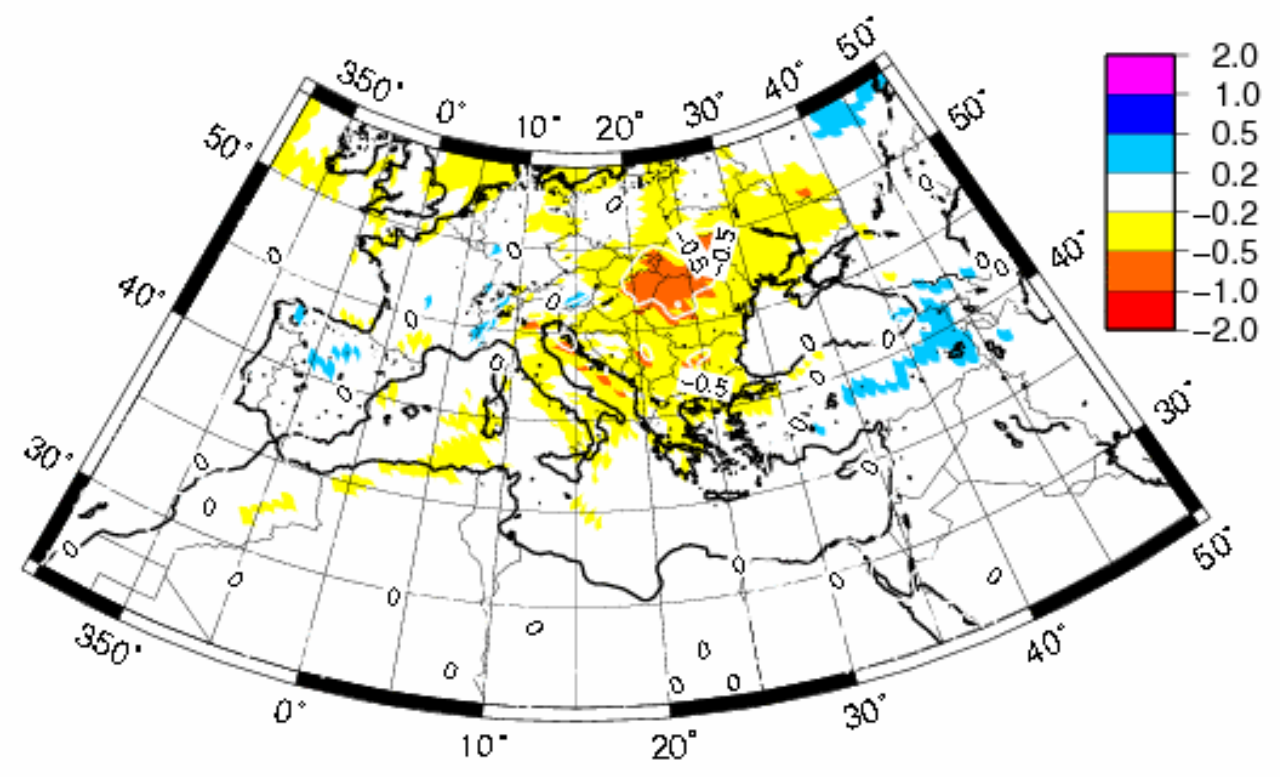

Figure 7: Same as Figure 3 but for precipitation (a) in winter and (b) in summer (in $\mathrm{mm} / \mathrm{d})$. 


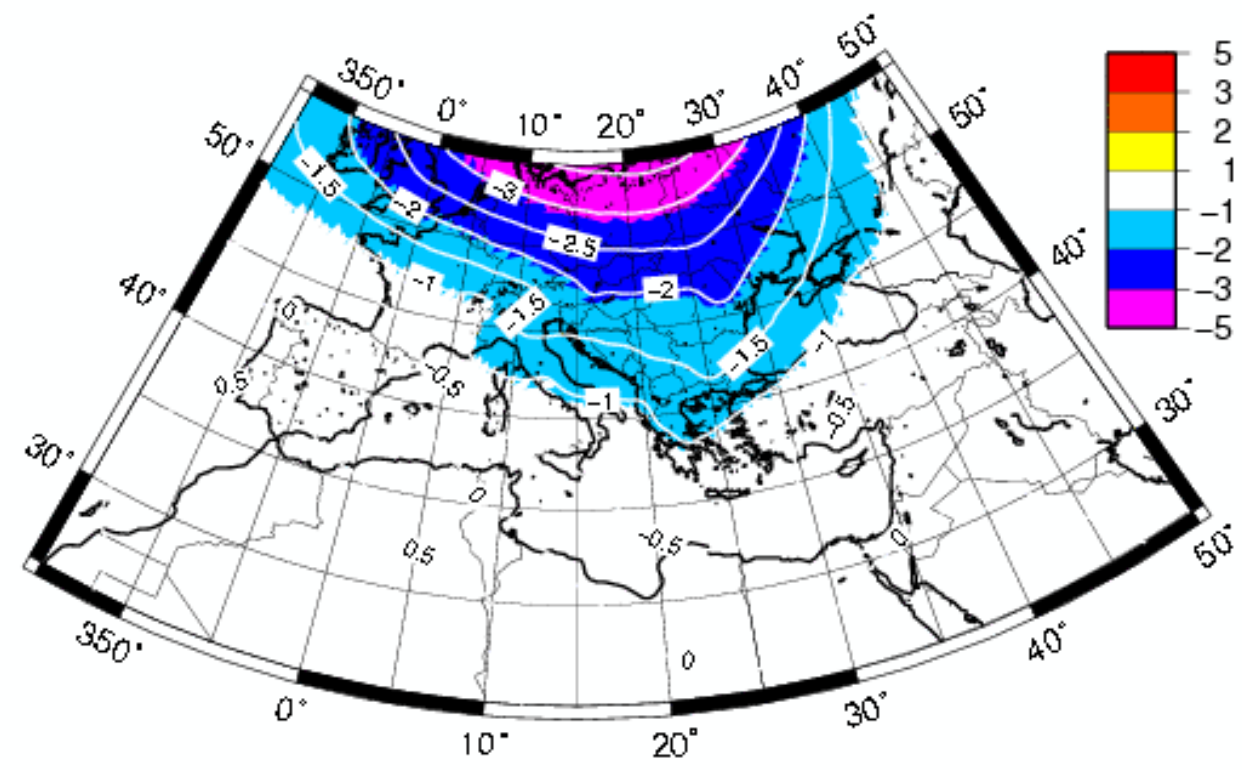

Figure 8: Same as Figure 3 but for mean sea level pressure (in $\mathrm{hPa}$ ) in winter.

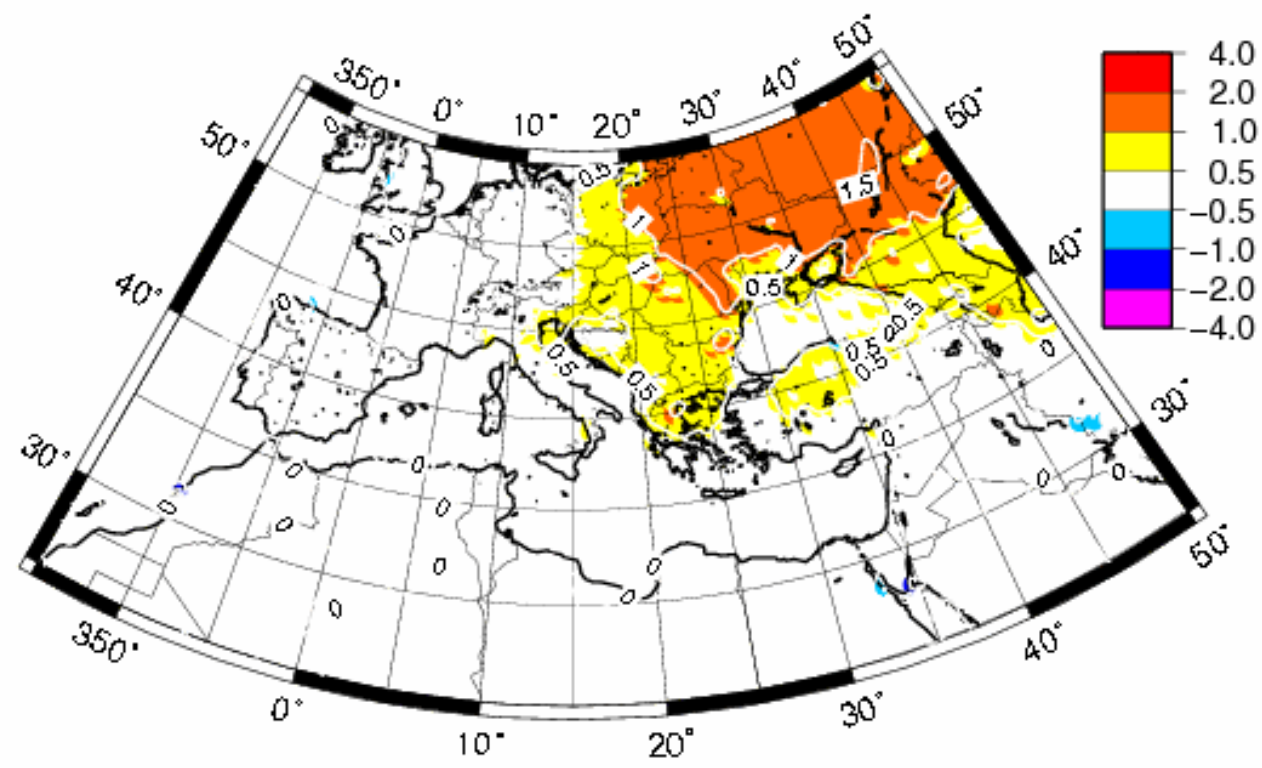

Figure 9: Same as Figure 3 but for $2 \mathrm{~m}$ temperature (in ${ }^{\circ} \mathrm{C}$ ) in spring. 


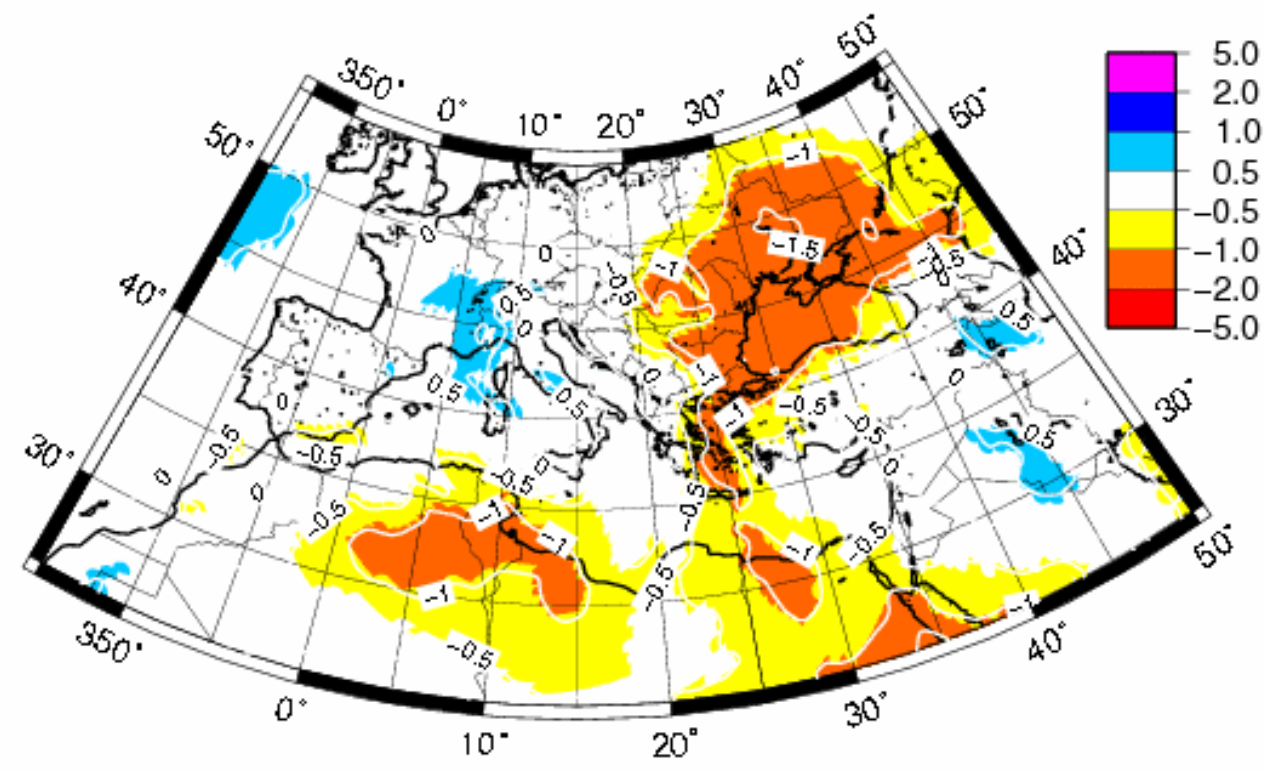

Figure 10: Same as Figure 3 but for atmosphere water vapour (in $\mathrm{mm}$ ) in summer.

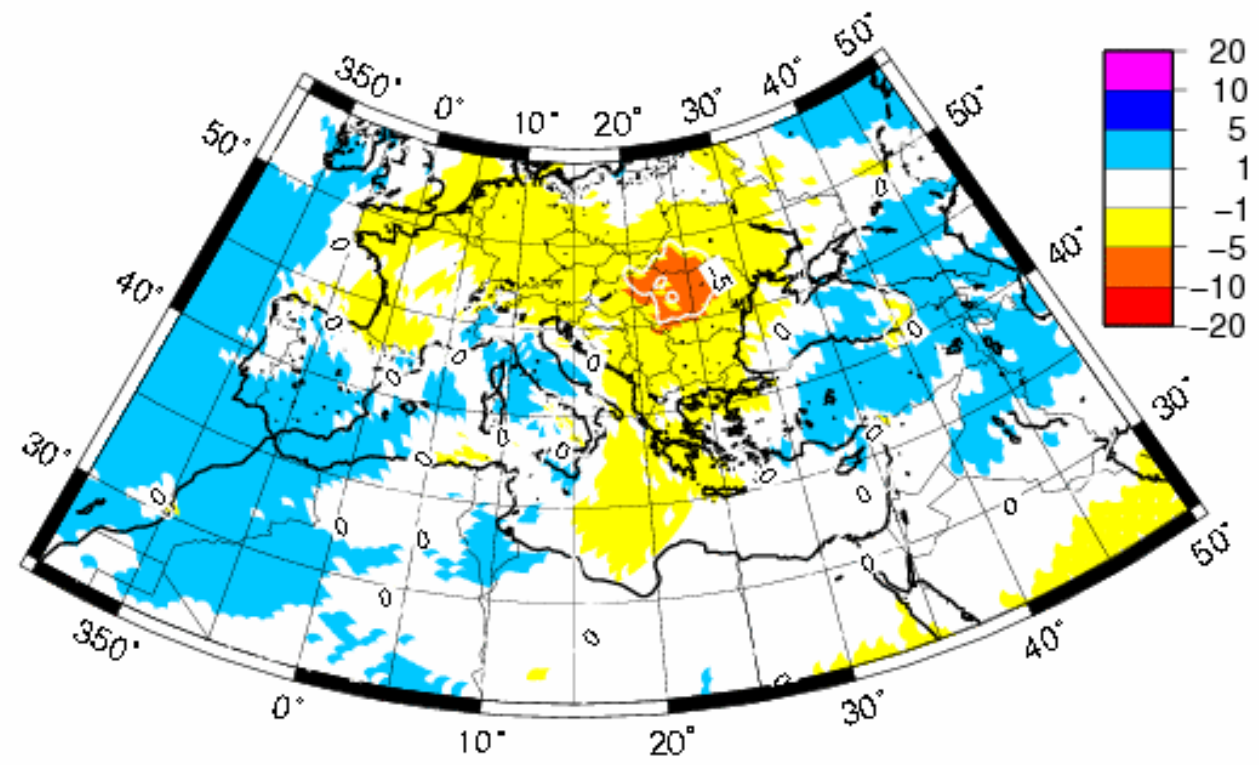

Figure 11: Same as Figure 3 but for nebulosity (in \%) in summer. 